\title{
REVIEW
}

\section{Experimental rodent models of prostatitis: limitations and potential}

\author{
EV Vykhovanets ${ }^{1}$, MI Resnick ${ }^{1,3}$, GT MacLennan ${ }^{2,3}$ and S Gupta ${ }^{1,3}$ \\ ${ }^{1}$ Department of Urology, Case Western Reserve University \& University Hospitals of Cleveland, Cleveland, OH, USA; ${ }^{2}$ Department \\ of Pathology, Case Western Reserve University \& University Hospitals of Cleveland, Cleveland, OH, USA and ${ }^{3}$ Ireland Cancer \\ Center, Cleveland, $\mathrm{OH}, \mathrm{USA}$
}

\begin{abstract}
Prostatitis is a polyetiological inflammation of the prostate gland in men characterized by pelvic pain, irritative voiding symptoms, and sexual dysfunction. Histologically prostatitis is characterized by poly- and mononuclear cell infiltrates (neutrophils, lymphocytes, macrophages and plasma cells) in the stromal connective tissue around the acini or ducts. Prostatitis is an important worldwide health problem in men. The pathogenesis and diagnostic criteria for the condition are obscure, with the result that the development of management programs for this condition has been hindered. Animal model(s) might be useful in elucidating mechanisms involved in the molecular pathogenesis of chronic nonbacterial prostatitis and chronic pelvic pain syndrome. Given that prostatitis might have a multifactorial etiology, several animal models with unique features may prove helpful. This review examines a number of experimental rodent models of prostatitis and evaluates their advantages and limitations.

Prostate Cancer and Prostatic Diseases (2007) 10, 15-29. doi:10.1038/sj.pcan.4500930; published online 2 January 2007
\end{abstract}

Keywords: prostatitis; inflammation; animal models

\section{Introduction}

Available data confirms that prostatitis is commonly diagnosed in men, in the US, with 2 million office visits recorded annually. ${ }^{1}$ Initial studies have estimated that up to $50 \%$ of men at some point in their life may suffer from prostate inflammation. ${ }^{2}$ More recent studies have recorded incidences of prostatitis ranging from 3 to $16 \%$ in North America, Europe and Asia ${ }^{1,3-9}$ half of whom will have repeat episodes ${ }^{10}$ emphasizing that prostatitis is an important worldwide health problem. Unlike benign prostate hyperplasia and prostate cancer, prostatitis affects adult men of all ages and is generally considered to be the most common outpatient condition seen in urologic practice in men younger than 50 years old. ${ }^{1}$ Moreover, prostatitis accounts for more office visits than either benign prostatic hyperplasia or prostate cancer. ${ }^{1}$

The most recent classification of prostatitis includes acute and chronic bacterial prostatitis (category I and II), chronic pelvic pain syndrome (CPPS) (category III) and asymptomatic inflammation of the prostate (category IV). ${ }^{11}$ The presence of white blood cells, commonly accepted uropathogens such as Escherichia coli, Enterococci spp, Klebsiella spp, Proteus spp and Pseudomanas

Correspondence: Dr S Gupta, Department of Urology, The James \& Eilleen Dicke Research Laboratory, Case Western Reserve University \& University Hospitals of Cleveland, 10900 Euclid Avenue,

Cleveland, OH 44106, USA.

E-mail: sanjay.gupta@case.edu

Received 20 September 2006; revised and accepted 23 October 2006; published online 2 January 2007 aeruginosa in the expressed prostatic secretions (EPS) and/or voided bladder, urine specimen and classic clinical symptoms can help to differentiate patients in categories I and II from patients in other categories. Asymptomatic inflammatory prostatitis (category IV) is diagnosed incidentally during patient evaluation of infertility, elevated serum prostate-specific antigen (PSA) or symptoms of benign prostatic hypertrophy. The majority of cases of prostatitis fall into category III also designated as chronic nonbacterial prostatitis/CPPS. Genitourinary pain with or without voiding symptoms in the absence of uropathogenic bacteria or other identifiable cause, such as malignancy, defines this category. Patients with chronic prostatitis/CPPS, however, are subcategorized into IIIA and IIIB subgroups. Pelvic pain lasting $>3$ months is an attribute of both subgroups but the presence of any number of white blood cells in the semen, postprostate massage urine specimen or EPS clearly distinguishes category IIIA from IIIB.

Infectious agents such as bacteria, Chlamydia or other microorganisms are implicated in $5-40 \%$ of cases of prostatitis. $^{10,12,13}$ The remaining $60-95 \%$ cases of clinical prostatitis (categories IIIA and IIIB) may involve (i) hormonal imbalance; ${ }^{14,15}$ (ii) neurological dysfunction; ${ }^{16,17}$ (iii) $\alpha$-adrenergic system abnormalities; ${ }^{18-20}$ (iv) urinary reflux into the prostate; ${ }^{21-23}(\mathrm{v})$ inappropriate cytokine release ${ }^{24-32}$ and/or (vi) an autoimmune response. $^{33-37}$ The patients typically have repeat episodes of prostatitis and therapy is 'hit or miss'. Quality-of-life may be significantly diminished. ${ }^{38}$ Furthermore, there is a growing awareness that chronic prostate inflammation may play a role in the development of prostatic 
cancer. $^{37,39-43}$ Recent analysis of follow-up prostate needle biopsies from 177 patients with clinical parameters suspicious for malignancy has revealed a strong association between chronic prostatic inflammation, and premalignant and malignant changes in prostatic epithelium. ${ }^{44}$

Reliable experimental animal models of human diseases are critically important for the discovery of molecular pathways, genetic influences, environmental factors, and successful management strategies for humans. Animals experimentally affected by such diseases provide a unique opportunity to uncover diseaseassociated pathways, which are complicated or even impossible to define in man. ${ }^{45}$ Currently, many human noncancer diseases have appropriate animal models that serve as sources for obtaining new research data and testing new therapeutic strategies. ${ }^{46-56}$ It should be noted that almost half the articles published on prostatitis and available on PubMed were published between the year 2000 and 2006. Nevertheless, the cause of category III and IV prostatitis has remained elusive. There is still no goldstandard diagnostic test for CPPS. ${ }^{57}$ During the last three decades considerable attention has been focused on creating novel reliable animal models of prostatic inflammation, in hope of uncovering its etiology and pathogenesis. Several rodent models have been developed, each with its own unique characteristics and potential has been summarized in Table 1 .

Human and rodent prostates are anatomically quite different. The rodent prostate is clearly divided into three or four lobes. ${ }^{58,59}$ The ventral lobe is the largest and rests on the ventral surface of the bladder. It is difficult to separate the dorsal and lateral lobes from each other in male mice or rats and both are harvested as one unit. The final lobe is the anterior prostate or coagulating gland. As it has been observed that neoplasms are usually derived from the dorsal-lateral lobe in rodents, ${ }^{60,61}$ it has been proposed that the dorsal-lateral lobe of the rodent prostate is analogous to the peripheral zone in the human prostate; however, this hypothesis currently has not been substantiated by histologic or biochemical evidence. Approximately, 30 human carcinoma cell lines putatively representing various stages of prostate cancer have been described and extensively used as powerful research tools. ${ }^{62}$ However, it should be noted that prostatitis is an inflammatory rather than a neoplastic disease. Consequently, cell cultures from normal or inflamed prostates are potentially limited in value in investigating prostatitis due to the restricted life span of nonmalignant prostate cells. The following is a review of studies conducted on several in vivo rodent models of prostatitis, including spontaneous, infectious models, hormone- and immune-induced, and some other models, with an attempt to assess their limitations and potential usefulness.

\section{Spontaneous prostatitis models}

\section{Rat models of prostatitis}

The development of spontaneous lobe-specific prostatitis is well documented for several rat strains. At approximately 12 weeks of age, $60-70 \%$ of male Lewis rats, developed spontaneous prostatitis in the lateral prostatic lobe. ${ }^{63}$ Sprague-Dawley male rats develop both ventral and lateral prostate inflammation at a significantly lower rate $(16 \%)$ at $22-24$ weeks age. ${ }^{64}$ In $77 \%$ of Wistar rats, spontaneous age dependent nonbacterial dorso-lateral prostatitis develops. ${ }^{65}$ By the age of 20 weeks, $88 \%$ of Copenhagen rats develop spontaneous lateral prostatic lobe inflammation; in contrast, prostatitis develops in only $6 \%$ of (Copenhagen $\times$ Fischer) 344 males. ${ }^{66}$ Naslund et al. ${ }^{67}$ reported that 12 -week-old Lewis, Wistar, and Sprague-Dawley males had a 30, 0 and $0 \%$ incidence of spontaneous lateral prostate inflammation, respectively; the incidence of this lobe specific nonbacterial prostate inflammation was increased considerably in older (40- to 52-week-old) Lewis (72\%) and Wistar (27\%) males, but not in Sprague-Dawley rats $(0 \%)$.

\section{Mouse models of prostatitis}

Data regarding the spontaneous prostate inflammation in mice is limited. Recently, Penna et al..$^{68}$ have shown that a strain of nonobese diabetic (NOD) mice develop spontaneous autoimmune prostatitis, which becomes apparent at $\sim 20$ weeks of age and remains stable. In this strain of NOD mice with type 1 insulin-dependent autoimmune diabetes, by the age 20-30 weeks the males exhibit prostate leukocyte infiltrates that are two to fourfold more numerous than seen in 8-week-old mice. A T-cell response to prostate antigens was detected in the spleens of unprimed 8-week-old NOD males. IFN- $\gamma$ may contribute to the pathogenesis of spontaneous prostatitis in NOD mice, since the development of prostatitis was markedly delayed in INF- $\gamma$-deficient NOD males. ${ }^{68}$ Unfortunately, the authors did not present the incidence rate and lobe specificity of spontaneous prostatitis in this mouse strain.

In summary, readily available Lewis, Wistar and Copenhagen male rats and NOD male mice develop spontaneous (lobe-specific in rats) nonbacterial prostatitis with advancing age, providing a model for the study of prostatic inflammation.

\section{Infectious prostatitis models}

From the clinical point of view an animal model of chronic bacterial prostatitis is clearly desirable. Acute bacterial prostatitis in men has well-defined criteria and management. ${ }^{69}$ On the other hand, chronic bacterial prostatitis is most often a consequence of acute bacterial prostate inflammation although the responsible pathogens may be fully sensitive to the antibiotics used for treatment, clearance of prostatic infection is often poor because of the limited ability of most antibiotics to achieve therapeutic levels within the prostate. ${ }^{70}$ Moreover, it seems likely that rather than being an infectious disease, its etiology and pathogenesis are diverse and its management remains a continuing challenge. ${ }^{71}$

\section{Rat models of prostatitis (categories I and II)}

The effects of androgen deprivation (castration) on experimental bacterial prostatitis in 10-week-old Sprague-Dawley male rats have been evaluated by Kaplan et al. ${ }^{72}$ Approximately $5 \times 10^{5}$ E. coli organisms originally isolated from the prostatic secretions of a patient with 
Table 1 Rodent models of prostate inflammation

\begin{tabular}{|c|c|c|c|}
\hline Model & Species and strain & Inflamed site (s) & Phenotype \\
\hline \multirow[t]{2}{*}{ Spontaneous } & $\begin{array}{l}\text { Rat: Wistar, Lewis, } \\
\text { Copenhagen }\end{array}$ & LL and VL & $\begin{array}{l}\text { Age- and strain-dependent (Sprague- } \\
\text { Dawley }<\text { Wistar }<\text { Copenhagen }<\text { Lewis) rat LL prostatitis }{ }^{63,65-67} \\
\text { as early as } 12 \text { weeks of age with a peak after } 20 \text { weeks of age; } \\
\text { PMNC and MNC prostate tissue infiltration }\end{array}$ \\
\hline & Mouse: NOD & NA & $\begin{array}{l}\text { Age-dependent prostatitis as early as } 20 \text { weeks of age with a } \\
\text { T-cell response to prostate } \mathrm{Ag}(\mathrm{s}) \text { at } 8 \text { weeks of age is highly } \\
\mathrm{CD} 4^{+} \text {cell adoptively transferable }{ }^{68}\end{array}$ \\
\hline \multirow[t]{2}{*}{ Infection } & $\begin{array}{l}\text { Rat: Wistar, } \\
\text { Sprague-Dawley, }\end{array}$ & VL, LL, DL & $\begin{array}{l}\text { Intraventral lobe } \text { or transurethral }^{73} \text { prostatic introduction of } \\
\text { E. coli present a model of acute (in } 100 \%) \text { prostatitis which is } \\
\text { self-limiting and chronic (in } \sim 50 \%) \text { whole prostate }{ }^{72} \text { and ventral } \\
\text { lobe prostatic inflammation }{ }^{73} \text { with high percentage of eliminated } \\
\text { animals due to their death or sterile prostate, }{ }^{77} \text { evidence that } \\
\text { an androgen deprivation might decrease bacterial growth and } \\
\text { improve course of chronic bacterial prostatitis. }{ }^{72,77} \text { Single } \\
\text { injection of Chlamydia trachomatis into vas deferens may generate } \\
\text { acute self-limited ( } \sim 80 \% \text { of cases) prostatitis }{ }^{76}\end{array}$ \\
\hline & $\begin{array}{l}\text { Mouse: } \mathrm{C} 3 \mathrm{H} / \mathrm{HeJ} \text { and } \\
\mathrm{C} 3 \mathrm{H} / \mathrm{HeOuJ}\end{array}$ & NA & $\begin{array}{l}\text { Both } \mathrm{C} 3 \mathrm{H} / \mathrm{HeJ} \text { and } \mathrm{C} 3 \mathrm{H} / \mathrm{HeOuJ} \text { male mice were able to develop } \\
\text { high acute prostate infection after inoculation intraurethrally } \\
\text { with E. coli; evidence that } \mathrm{C} 3 \mathrm{H} / \mathrm{HeOuJ} \text { mice have signs of acute } \\
\text { purulent (on the first week) and chronic (on } 12 \text { and } 26 \text { week) } \\
\text { prostatitis after E. coli inoculation }\end{array}$ \\
\hline
\end{tabular}

Immune

Prostate Rat: Wistar, Lewis,

Ag-induced Copenhagen

Mouse: C57BL/6 and NOD

NA

Day 3 of life thymectomy (Tx-3)

Mouse: C3, 129 $(\mathrm{C} 57 \mathrm{BL} / 6 \mathrm{~N} \times \mathrm{A} / \mathrm{J}) \mathrm{F}_{1}$ $(\mathrm{C} 3 \mathrm{H} / \mathrm{HeMs} \times 129 / \mathrm{J}) \mathrm{F}_{1}$ and $(\mathrm{SWR} \times \mathrm{NZB}) \mathrm{F}_{1}$

Immune manipulation

Mouse: TRAMP and POET

LL, DL and VL glands, DL, LL and VL

$\mathrm{VL}<\mathrm{DL}=\mathrm{LL}<\mathrm{AL}$

Rat: Wistar, Lewis

LL, LL/DL and VL

Mouse: LuRKO

NA

$\mathrm{DL}, \mathrm{LL}<\mathrm{VL}$

VP
Single/multiple immunization of homogenate of rat male sex accessory glands,${ }^{82}$ rat prostate tissue, ${ }^{94}$ rat or human prostate acid phosphatase, ${ }^{92}$ or rat prostate steroid binding protein $(\mathrm{PSBP})^{94}$ with CFA induces accumulation of circulating $\mathrm{Ab}$ to prostate $\mathrm{Ag}(\mathrm{s})$ and low incidence rate $(\sim 30 \%)$ of MNC prostatitis for 1-2 months and is high cell adoptively transferable Single/multiple immunization of homogenate of rat male sex accessory glands, ${ }^{100}$ rat prostate tissue, ${ }^{101}$ mouse prostate homogenate, ${ }^{68,97}$ purified rat or mouse PSBP, ${ }^{68}$ and synthetic mouse PSBP peptides ${ }^{68}$ with CFA induces different incidence rate (from $30^{101}$ to $100 \%{ }^{97}$ ) of mononuclear cell prostatitis, accumulation of circulating auto-Abs to prostate $\mathrm{Ag}(\mathrm{s})$, and is high cell adoptively transferable

No any sensitization with tissue $\mathrm{Ag}(\mathrm{s})$. Tx-3 induces non-specific MNC prostate infiltration in $\sim 60 \%$ of males on 50-210 day of age $^{102,107}$ with accumulation of circulating auto-Abs to prostate tissue in $70-97 \%$ of mice. ${ }^{102-104,108} \mathrm{Tx}-3$ mice develop prostatitis by auto-sensitization to the $\mathrm{Ag}(\mathrm{s})$ normally expressing in the differentiated prostate and it is highly adoptive cell transferable and can be prevented by $\mathrm{CD} 4^{+}$spleen cells from normal males

Simultaneous vaccination with tumor cells and treatment with CTLA-4 induces an enhanced immune response, at least in part, to normal prostate $\mathrm{Ag}(\mathrm{s})$ and prostate MNC infiltration. ${ }^{121}$ Transitory prostatitis, without induction of prostate pathology, was induced by transfer of prostate antigen specific $\mathrm{CD} 8^{+}$ cytotoxic cells ${ }^{124}$

Strain, lobe-specific and age-dependent prostatitis. $17 \beta$-estradiol given to male adults increases incidence and severity of spontaneous prostatitis that can be attenuated by testosterone but not DHT. ${ }^{67,129}$ Testosterone treatment during adulthood induces LL and VL prostatitis only after estrogen neonatal imprinting. ${ }^{67}$ The model relays with hyperprolactinemia ${ }^{40}$ and accumulation of autoreactive cells in inflamed prostate ${ }^{151}$ Testosterone replacement from 21 day for 60 day of age induces severe PMNC and MNC prostate infiltration in $67 \%$ of hypogonodal LuRKO mice which may be related to the disturbance of sperm transport to ejaculated semen in the treated males $^{162}$

Long-term (10 days) stress stimuli (starvation, low surrounding temperature, and small cage) induce prostatic inflammation ${ }^{168}$

Transurethral ethanol/dinitrobenzenesulfonic acid-mediated mucosal injury resulted in acute prostatitis that is peaked between 24 and $48 \mathrm{~h}^{169}$ 
Table 1 Continued

\begin{tabular}{|c|c|c|c|}
\hline Model & Species and strain & Inflamed site (s) & Phenotype \\
\hline Diet & Rat: Sprague-Dawley & LL, DL & $\begin{array}{l}\text { Both } 9 \text { week oral administration of soy been extract mixture }{ }^{170} \\
\text { and } 11 \text { week soy-free diet }{ }^{64} \text { were able to induce LL/DL prostatitis } \\
\text { in } 80 \% \text { of rat males that may suggest for role of the estrogen/ } \\
\text { androgen balance in initiating prostate inflammation }\end{array}$ \\
\hline Mechanical & Rat: Wistar & VL & $\begin{array}{l}\text { Partial mechanical obstruction of the urethra induces prostatic } \\
\text { lymphocytic infiltration and interstitial edema, being most } \\
\text { prominent on day } 3 \text { that might be due to intraprostatic urinary } \\
\text { reflux }\end{array}$ \\
\hline
\end{tabular}

Abbreviations: AL, DL, LL, VL, anterior, dorsal, lateral, ventral (coagulating gland) lobes of prostate, respectively; CFA, complete Freund's adjuvant; DHT, dihydrotestosterone propionate; MNC, mononuclear cells; NA, not applicable; PMNC, polymorphonuclear cells; Tx-3, day 3 thymectomized

chronic bacterial prostatitis were directly injected into one of the ventral prostatic lobes using a midline abdominal surgical incision. All prostatic lobes showed signs of marked acute inflammation by day 4 following injection. On day 18, however, the ventral prostates from intact rats had little evidence of inflammation but those from the castrated animals still showed a strong inflammatory reaction, although ventral prostate tissue from both were aseptic. In contrast to the ventral prostatic lobe, the dorso-lateral prostate in intact rats showed evidence of developing chronic bacterial prostatitis and tissue cultures remained positive for E. coli. ${ }^{72}$

In the early 1990s, Nickel et al. ${ }^{73}$ developed a novel protocol to induce acute and chronic bacterial prostatitis in 10- to 12-week-old Sprague-Dawley male rats. The retrograde inoculation of $2 \times 10^{7}$ colony-forming units of E. coli K-235 into the duct of the ventral prostatic gland via a calibrated catheter lodged in the proximal urethrainduced acute prostatitis within 3 days in all glands. However, approximately $50 \%$ of the animals overcame their infections spontaneously and did not develop chronic prostatitis during the next 6 weeks. Although it was not clear whether the dorso-lateral prostate was involved or not this model demonstrated two distinct histological phases of bacterial inflammation in the ventral prostate. ${ }^{73}$ During the initial acute infection stage (days 1-14) an acute response to the bacterial challenge with florid infiltration of polymorphonuclear cells into bacteria-containing spaces was observed. ${ }^{74}$ As the infections became chronic, heavy lymphocyte infiltration and fibrous tissue proliferation completely engulfed the ventral prostatic lobe. Although the inflammatory process in the human prostate remains localized to the gland itself, an intense serum immune reaction mounted against the specific $E$. coli is detectable during the chronic phase of disease at day 56 postinfection. ${ }^{74}$

Infectious agents other than $E$. coli have been used to induce prostate inflammation in rats. Intraurethral injection of Chlamydia organisms or placement of a drop of a suspension of Chlamydia organisms on the meatus of the extruded penis resulted in transient urethritis and cystitis but not prostatitis in male guinea pigs. ${ }^{75}$ However, a more aggressive approach, inoculating Chlamydia psittaci into the right vas deference has been reported to induce prostate inflammation in 10- to 12 -week-old male Wistar rats. ${ }^{76}$ Although the specific site of inflammation in rat prostates was not stated, it was observed that $100 \%$ of the inoculated animals had purulent prostatitis both on day 7 and 14 post- injection. By day 30, however, prostate tissue samples were negative for C. psittaci in more than $80 \%$ of infected rats.

Seo et $a .^{77}$ conducted studies of chronic bacterial prostatitis using the Nickel's model. Approximately, 62\% of 12- to 16-week-old male Wistar rats develop chronic bacterial prostatitis by 4 weeks after instillation of $2 \times 10^{7}$ colony-forming units of E. coli Z-17 into the urethra. The other $38 \%$ of the rats developed severe acute inflammation in the prostate, or died of sepsis, or did not develop prostatitis. In contrast to a previous study, ${ }^{73}$ only $8 \%$ of rats showed spontaneous resolution of chronic bacterial prostatitis, perhaps indicating that Wistar rats are particularly susceptible to bacterial prostatitis, or that E. coli Z-17 is particularly efficient in inducing prostate inflammation. Bacterial growth in prostate and urine samples and also prostate histological patterns (degree of inflammatory cell infiltration, acinar changes, interstitial fibrosis) were used to evaluate the effects of various androgen deprivation models on the course of chronic bacterial prostatitis. Although untreated, castrated, and $17 \alpha$-estradiol $(50 \mathrm{mg} / \mathrm{kg} /$ day)-treated rats with chronic bacterial prostatitis shown similar ventral prostate histological patterns, 4 week administration of finasteride $(10 \mathrm{mg} / \mathrm{kg} /$ day) or levofloxacin $(100 \mathrm{mg} / \mathrm{kg} /$ day $)$ was able to decrease inflammatory cell infiltration and acinar appearances of inflamed prostates. Again only the finasteride and levofloxacin could reduce significantly bacterial growth both in prostate tissue and urine cultures. In general, authors demonstrated that among other models of androgen deprivation, finasteride was 1.5- to twofold more effective modality to improve course of chronic bacterial prostatitis in the animal model without reducing the systemic testosterone levels. ${ }^{77}$ More recent studies have evaluated the antibacterial effects of intraprostatic zinc injection ${ }^{78}$ and synergistic effects of catechin treatment (extract of green tea) combined with the antibiotic ciprofloxacin in the experimental rat model of chronic bacterial prostatitis. $^{79}$

Accumulated evidence suggests that rodent models of experimentally induced prostate inflammation (categories I and II) share many striking similarities to the development and persistence of human chronic bacterial prostatitis, possible comparable to the natural history of the disease. ${ }^{73}$ Furthermore, retrograde intraurethral introduction of infectious agent appears to be the most efficient means of inducing bacterial prostatitis in rodents. However, some disadvantages in this model are significant proportion (from 8 to 50\%) of rats 
subjected to intrauretheral injection do not develop chronic prostatitis; for a variety of reasons, including spontaneous clearance of infection and death from sepsis.

\section{Mouse models of prostatitis (categories I and II)}

Prostate infection intensities in genetically different mouse strains after induction of prostatitis with uropathogenic strains of $E$. coli were recently assessed. ${ }^{80}$ Although these did not include histologic assessment of prostate tissue, it was demonstrated that male BALB/c, $\mathrm{C} 57 \mathrm{BL} / 6 \mathrm{~J}$ and $(\mathrm{BALB} / \mathrm{c} \times \mathrm{C} 3 \mathrm{H} / \mathrm{HeJ}) \mathrm{F}_{1}$ mice 13 weeks of age showed no apparent prostate infection 5 days after intraurethral inoculation with $E$. coli. In contrast, $\mathrm{C} 3 \mathrm{H} /$ $\mathrm{HeJ}$ and $\mathrm{C} 3 \mathrm{H} / \mathrm{HeOuJ}$ mice exhibited a high incidence of acute prostate infection at the same time point. More recently, acute purulent bacterial prostatitis in male $\mathrm{C} 3 \mathrm{H} / \mathrm{HeOuJ}$ mice 12-week-old after intraurethral inoculation with $2 \times 10^{6}$ E. coli 1677 was histologically confirmed on day 5 postinfection. ${ }^{81}$ Moreover, chronic prostatic inflammation was evident at 12 and 26 weeks postinoculation and was associated with reactive epithelial hyperplasia, glandular atypia and evidence of oxidative stress in prostate tissues.

Given the preliminary data available it is difficult to estimate the potential usefulness of this mouse model of acute and chronic bacterial (categories I and II) prostatitis. However, this model may be advantageous because the mouse strains are readily available, and the inoculated mice do develop chronic prostatitis, a feature that might be exploitable in studies evaluating the possible influence of chronic inflammation on the development of prostate cancer. At this point, because available data is limited, it is unclear whether the findings in this study are readily reproducible. Further studies are needed to ascertain whether this model will prove useful.

\section{Immune-induced prostatitis models}

\section{Antigen-induced rat prostatitis models (category III)}

An autoimmune model for antigen-induced prostatic inflammation in rodents was first described by PachecoRupil et al. ${ }^{82}$ Male accessory gland (MAG) homogenate (prostate, seminal vesicles and coagulating glands) (15.0 mg total protein) with complete Freund's adjuvant (CFA) from Wistar rats was subcutaneously (s.c.) injected once on day 0 or twice on day 0 and 15 into syngeneic rats as antigenic material. An inflammatory reaction in the prostate was observed in three of eight rats $(38 \%)$ on day 21 after a single inoculation of MAG. Repeating the antigen challenge resulted in a slight increase in the incidence of prostatitis $(9 / 20,45 \%)$ by day 30 . No circulating antibodies were detected in rats after a single injection of MAG. However, more intense and prolonged immunization schedules induced humoral responses. ${ }^{82}$ Further variations in the doses and immunization schedules of MAG and various chemical modifications failed to increase the incidence of prostatitis. Typically, rat prostate morphology during the fifth week after antigen challenge was characterized by MNC infiltration into the interstitium, primarily centered around blood vessels close to the epithelium. In some animals, the inflammatory process induced fibrosis with enlargement of the acini and accumulation of mast cells in the stroma of the inflamed prostate. The number of MNC in prostate inflammatory foci increased on day 14 and reached the highest levels on day 28 after the first immunization with MAG. The foci were constituted with both $\mathrm{CD}^{+}{ }^{+}$and $\mathrm{CD} 8{ }^{+}$T cells on the 14 and 28 day after the immunization. Only scarce macrophages were found in the prostate inflammatory foci of MAG-treated rats. ${ }^{83}$

Studies have shown that antigen components of the MAG are capable of inducing T-cell proliferation in vitro $^{84}$ and the accumulation of auto-antibodies in the serum of immunized rats. ${ }^{85}$ High percentage $(\sim 70-80 \%)$ of male syngeneic recipients exhibited inflammation in the prostate; however, no humoral immune responses were detected in these recipients after cell transfer of MNC from donors with MAG-induced prostatitis. ${ }^{86}$ Galmarini et al. ${ }^{87}$ used 3 months old male Wistar rats immunized with chemically modified MAG (MAG was coupled to diazonium derivates of arsenilic and sulphanilic acid which act as adjuvant) once, twice or three times on days 0,30 and 45. Inoculation of MAG was necessary to confer higher titers of antibody. Histological changes in the target organs (coagulating glands and prostate $\gg$ seminal vesicle) were evident in almost all animals examined at 35, 42 and 49 days after the first injection of modified MAG and were characterized by inflammatory reactions and small perivascular mononuclear infiltrates. ${ }^{87}$ Thus, this model is consistent with a self-limiting mild to moderate prostate inflammation induced by both humoral and cell-mediated mechanisms. ${ }^{88}$ It has been speculated that inflammatory damage induced in this model might be the result of generation of autoreactive cytotoxic cells, increased levels of radical oxidative species from prostatic infiltrating macrophages, and upregulated mast cell degranulation. ${ }^{89-91}$ These studies do not identify the specific prostatic proteins that are the targets on an immune response. The immunogenicity of prostatic acid phosphatase (PAP) as a target for the induction of an immune response in 6- to 8-week-old Copenhagen rat was investigated by Fong et al. ${ }^{92}$ They demonstrated that immunization with recombinant rat or human PAP leads to a significant antibody response, 4 weeks after the final boost, but does not generate cytotoxic T lymphocytes (CTL) or result in autoimmune prostatitis. ${ }^{92}$ In contrast, intravenous immunization with recombinant vaccinia virus expressing human PAP generated a CTL response and tissuespecific prostatitis in the absence of detectable PAPspecific antibody. Destructive prostatitis was detected in $80 \%$ of cases and interstitial inflammation was found in the remaining $20 \%$ of cases. These finding suggest that a cellular immune response to PAP, rather than antibody, mediates destructive autoimmune prostate inflammation. In this model, sensitization of the immune system to xeno-antigen leads to the generation of $\mathrm{T}$ lymphocytes that can cross-react with self-PAP or, alternatively, to the phenomenon of epitope spreading that results in tissuespecific inflammation and destruction of the prostate gland. ${ }^{92}$ The authors of this study did not specify the precise areas of the prostate that were involved in inflammation.

Although prostate steroid-binding protein (PSBP) has immunosuppressive activities, ${ }^{93}$ it was identified as the 
dominant antigenic target in another rat model of prostate inflammation. ${ }^{94}$ PSBP is the major secretory protein in the rat ventral prostate, and so far it has not been found in any other organ. The authors used ventral prostate homogenate from pooled prostates of Lewis rats as a source of prostate antigen(s) to triple immunize 3-6 months old male syngeneic rats. This protocol did not induce prostate inflammation but resulted in the generation of high levels of auto-antibodies to PSBP. In contrast with the results using prostate homogenate significant focal inflammation of the ventral prostate was observed in four of 12 rats (33\%) immunized with ion exchange chromatography-purified rat PSBP, a procedure that elicited both humoral and cellular responses against PSBP. Moreover, adoptive cell transfer experiments have shown that splenocytes from PSBP immunized donors were capable of inducing severe ventral prostate inflammation in five of eight rats $(63 \%)$ even if the donors of the splenocytes did not have prostatitis. ${ }^{94}$ Similar results were obtained when PSBP was used to immunize 3-month-old male Wistar rats. ${ }^{95}$ The autoimmune response was characterized by delayed type hyper-sensitivity reaction accompanied by autoantibody production and increased degranulation of mast cells in the rat prostate gland. However, the authors emphasized that although PSBP was able to induce autoimmune prostatitis, the stronger autoimmune responses and the differences in the lesion observed in animals immunized with a prostate homogenate (which includes a wider spectrum of prostate antigen(s)) indicate that more than one auto-antigen was involved, as is typically the case other autoimmune disorders. ${ }^{95}$

Antigen-induced autoimmune prostate inflammation was used by Gilardoni et al. ${ }^{96}$ as a background for longterm (20 weeks) hormonal treatment with testosterone (silastic membrane tubes, $45 \mathrm{mg} /$ implant, placed 45 days after the first MAG immunization) in combination with a carcinogenic agent $(7,12$ demithylbenz $(\alpha)$ anthracene (DMBA), $30 \mathrm{mg} / \mathrm{kg}$, 28 days after the 1st immunization with MAG) in male Wistar rats. Histologic evaluation showed the presence of premalignant lesions (prostatic intraepithelial neoplasia) in five of 10 rats $(50 \%)$ that were challenged with MAG's proteins. The development of prostate carcinoma in animals treated with testosterone and DMBA was seen only in animals in which prostate inflammation had previously been induced by MAG immunization. Controls animals exposed to testosterone and DMBA alone were found to have prostatic intraepithelial neoplasia, but did not develop carcinoma. ${ }^{96}$ This model of category III prostatic inflammation has several advantages. The protocol for inducing it is fairly simple and the susceptible rat strains are readily available. It shows promise as a potential model for the investigation of possible relationship between prostatic inflammation and the development of prostate cancer. However, the disadvantage of this model includes: (i) prostatitis is induced by one or more proteins that have not so far been identified; (ii) only $\sim 30-50 \%$ of immunized animals develop prostatitis; (iii) the autoreactive T-cell subset responsible for the autoimmune prostatitis is activated by immunization with an ill-defined mix of prostate proteins or PSBP. Finally, despite impressive findings in two elegant studies, ${ }^{92,94}$ these models have not been used and the findings have not been reported by others.
Antigen-induced mouse prostatitis models (category III) Keetch et al. ${ }^{97}$ reported in the mid 1990s one of the first mouse models of antigen-induced prostate inflammation. They reported that $100 \%$ of $\mathrm{C} 57 \mathrm{BL} / 6$ male mice immunized once with prostate tissue extract developed autoimmune prostatitis by day 30 . Only ventral lobes of the prostate from syngeneic mice were used for preparation of the extract and the extract was combined with CFA. Mice were immunized with different doses, up to a maximum of $0.75 \mathrm{mg}$ protein extract and supplemented with pertussis toxin. A prominent interstitial infiltration of MNC was noted, predominantly surrounding blood vessels and prostatic acini. The inflammation was localized to the dorso-lateral prostate and the degree of inflammation was dose-dependent. The authors were able to induce prostatitis in syngeneic naive recipients by adoptive cell transfer. The autoimmune nature of the induced prostatitis was supported by the identification of circulating serum antibodies to unknown prostatic homogenate proteins with molecular weight $25 \mathrm{kDa}$. This study demonstrated that the $\mathrm{C} 57 \mathrm{bl} / 6$ mouse strain was more susceptible to the induction of prostatitis than other strains such as SJA, AJ and Balb/c. ${ }^{97}$

NOD mice are a well-characterized model of type I diabetes. They are also prone to develop inflammatory reactions in multiple exocrine and endocrine glands including the salivary and lachrymal glands, ${ }^{8}$ and the thyroid. ${ }^{99}$ Rivero et al. ${ }^{100}$ studied the induction of urogenital organ inflammation in NOD mice after xenoantigen challenge. They demonstrated that 10 days and 21 days after vaccination with $1.0 \mathrm{mg}$ pooled MAG homogenate from Wistar rats with CFA, all mice showed inflammation in the dorso-lateral prostate, regardless of whether they had been exposed once or twice to MAG in CFA. Additionally, foci of moderately severe inflammation were also found in the ventral prostate, seminal vesicles and coagulating glands, although less frequently. Further experiments by the same group have shown that $1.0 \mathrm{mg}$ Wistar rat prostate homogenate or $30 \mu \mathrm{g}$ of Wistar rat PSBP injected twice resulted in the induction of prostatitis in $80-100 \%$ of young male NOD mice but in only $\sim 30 \%$ of C57BL/ 6 mice. ${ }^{10}$ Although precise sites of prostate inflammation were not specified in this study, histologic changes in the prostate were characterized by perivascular and stromal MNC infiltration accompanied by edema. The edema was more severe in mice immunized with prostate homogenate than in those immunized by PSBP. These experiments with NOD mice also demonstrated that immunized mice specifically responded to prostate xenoantigen(s) challenge by increased T-cell proliferation, increased release of INF- $\gamma$ by upregulated T cells, and by increased production of circulating IgM and IgG autoantibodies. More recently, it was reported that NOD mice are characterized by the spontaneous development of autoimmune prostatitis which becomes apparent at about 20 weeks of age and is stably maintained thereafter. ${ }^{68}$ In contrast to BALB/c and C57BL/6 mice, significant upregulation of PSBPspecific autoreactive T cells are detectable in NOD males before the spontaneous development of autoimmune prostatitis, indicating lack of tolerance to the self-antigen. There are indications that disease development was markedly delayed in IFN- $\gamma$-deficient mice and prostate lymphocyte infiltration could be transferred into NOD.SCID recipients by $\mathrm{CD}^{+}$cells from 24-week-old NOD 
males. Experimental autoimmune prostatitis was detected in NOD mice 30 days after priming of 8-week-old NOD males with mouse prostate homogenate, purified PSBP, and synthetic PSBP peptides. Moreover, both PSBP and prostate homogenate induced comparable levels of intraprostatic $\mathrm{CD}^{+}{ }^{+}$cell infiltration of NOD mice. ${ }^{68}$ The advantages of this mouse model of category III prostatitis are that (i) relevant mouse strains are readily available, and that there is a wide variety of immunological techniques available to study of immunological aspects underlying prostatic inflammation. On the other hand, the major disadvantage of this model is that the prostate tissue autoantigen involved in the induction of autoimmune prostatitis is not well characterized. Furthermore, NOD mice frequently develop diabetes and other organ-specific autoimmune diseases that may interfere to specify study of prostate inflammation.

\section{T regulatory cell depleted mouse model}

Taguchi et al. ${ }^{102-103}$ described another immune-mediated model of prostate inflammation in the mid-1980s. They reported that $\sim 70 \%$ of $\mathrm{C} 3 \mathrm{H} / \mathrm{HeMs} \times 129 / \mathrm{J} \mathrm{F}_{1}$ male mice that were thymectomized on day 3 (Tx-3) developed prostatitis which was found predominantly in the anterior prostate (coagulating gland) and to a much lesser degree in the ventral prostate. ${ }^{102,103}$ The autoimmune prostatitis was characterized by loss of secretory products in the lumen and massive lymphocyte infiltration in the stroma (beneath the epithelial cells). Marked inflammation in the prostate was accompanied by circulating autoantibodies to prostate epithelial cells in 42 of 60 cases $(70 \%)$ of Tx-3 mice aged 50-150 days. The authors observed that performing a thymectomy on day 0 or 7 of life did not reproduce this phenotype and castration on day 0 (Orx-0) of life eradicated it. At the same time, seven of 13 Orx- $0+$ Tx-3 mice (54\%) developed autoimmune prostatitis when they were given a testosterone pellet at 90 day of age. These data indicate that Tx-3 mice develop autoimmune prostatitis by autosensitization of the immune system to an unknown prostate antigen(s) normally expressed in the differentiated prostate gland. In the mid 1990s, Taguchi et al. ${ }^{104}$ reported that depletion of the tissue-specific $\mathrm{CD}^{+}{ }^{+} \mathrm{T}$ suppressor cell population in $\mathrm{Tx}-3$ mice results in autoimmune prostatitis after the onset of puberty. They demonstrated that the development of the prostate lesions in $\mathrm{Tx}-3(\mathrm{C} 57 \mathrm{BL} / 6 \mathrm{~N} \times \mathrm{A} / \mathrm{J}) \mathrm{F}_{1}$ male mice could be prevented by a single injection of $\mathrm{CD}^{+}$spleen cells from normal syngeneic mice, but not from normal females or Orx- 0 mice. However, the splenocytes from Orx- 0 mice could prevent prostatitis in Tx-3 recipients if the Orx-0 donors had received a dihydrotestosterone (DHT) pellet in adulthood, resulting in prostate maturation. The data of this elegant study indicate that immune tolerance to prostate antigen(s) is maintained by a tissuespecific $\mathrm{T}$ regulatory cell subset, which is activated by a specific auto-antigen(s) in the mature prostate. The autoimmune nature of prostatitis in the studied mice was also supportive by induction of prostate inflammation in nude recipients after adoptive cell transfer of autoreactive $\mathrm{CD}^{+}$cells from syngeneic Tx-3 mice with prostatitis. Moreover, the findings that even $\mathrm{CD}^{+}{ }^{+}$cells from Orx- 0 mice that were thymectomized as adults and treated thereafter with DHT were effective in preventing

prostatitis may suggest that activation of this T suppressor population takes place in the peripheral lymphoid organs. ${ }^{104}$ It is clear that depletion of CD $4^{+} \mathrm{CD} 25^{+} \mathrm{T}$ regulatory cells by 3 day thymectomy in this model is an underlying cause of prostatitis. ${ }^{105,106}$ More recently, Bagavant et al. ${ }^{107}$ have reported that eight of $13(62 \%)$ of Tx-3 lupus-prone $(\mathrm{NZB} \times \mathrm{SWR}) \mathrm{F}_{1}$ male mice developed prostatitis and antibody to PSAs was found in 11 of 15 cases $(73 \%)$. These authors also reported that prostatitis was detected in $73 \%$ of $\mathrm{Tx}-3$ males of another lupus-prone mouse strain (NZM2328). ${ }^{108}$ It has been also shown that the transfer of 1 million $\mathrm{CD}_{25}{ }^{+} \mathrm{T}$ cells to $\mathrm{Tx}-3$ NZM2328 mice completely suppressed prostatitis. In summary, these data strongly suggest the role of $\mathrm{T}$ regulatory cells in this model of prostate inflammation.

The advantage of this mouse model of prostatic inflammation is that it appears to be a genuine disease that offers an opportunity to study the basic principles of self-tolerance. However, the disadvantages are that the model is too artificial and not specific. Indeed, these Tx-3 mice also develop thyroiditis, ${ }^{109}$ oophoritis, ${ }^{110}$ gastritis, ${ }^{111}$ orhitis ${ }^{112}$ and insulitis. ${ }^{113}$ Furthermore, the percentage mortality from surgery was not listed in the available publications; however, it is clear that complete thymectomy is a challenging exercise in the newborn mice.

\section{Other immune induced mouse prostatitis models}

The cytotoxic $\mathrm{T}$ lymphocyte antigen-4 (CTLA-4) is a second $\mathrm{T}$ cell counter-receptor for surface B7 molecule ${ }^{114}$ that plays a critical role in attenuating $\mathrm{T}$-cell responses. CTLA-4 engagement may inhibit the initiation of $\mathrm{T}$ cell responses by raising the threshold of signals needed for full activation, or may also play a role in terminating ongoing T-cell responses. ${ }^{115,116}$ Anti-CTLA-4 antibodies that block CTLA-4/B7 interactions enhance in vivo T-cell responses to peptides, superantigens and parasites, and can exacerbate experimental autoimmune encephalomyelitis ${ }^{115}$ or induce the rejection of newly implanted and well established tumors in several transplantable murine tumor systems. ${ }^{117-120}$ Hurwitz et al. ${ }^{121}$ used CTLA-4 blockade to immunotherapy of primary prostate cancer in transgenic mouse model. They showed that significant accumulation of inflammatory cells in prostate interductal spaces when TRAMP mice were treated with anti-CTLA-4 and a granulocyte-macrophage colony-stimulating factor (GM-CSF) expressing tumorderived vaccine account for a significant reduction of tumor incidence. The authors demonstrated that antitumor response is directed against antigen(s) expressed by both prostate adenocarcinoma and normal prostate, because immunization of nontransgenic mice with GMCSF-expressing tumor cell vaccines under conditions of CTLA-4 blockade can also result in marked dorso-lateral prostatitis evident 28 days post-treatment. However, they found no evidence of significant inflammation or tissue damage in the dorso-lateral or ventral lobes of the prostates of nontransgenic mice immunized only with GM-CSF tumor vaccine. ${ }^{121}$

While several models have addressed the generalized response to prostate antigen(s), these models did not examine antigen specific T-cell populations during responses. ${ }^{92,94,95}$ To address the problem of inability to 
monitor specific T-cell populations in prostate inflammation, the prostate ovalbumin-expressing transgenic (POET-1) mouse model was developed. POET-1 mice express a membrane-bound ovalbumin fusion protein (mOVA) at high levels in the ventral and dorso-lateral prostate lobes following adolescence. ${ }^{122,123}$ The relative specificity of the mOVA for high-level prostate expression was demonstrated by Lees et al. ${ }^{124}$ with a system studying the effects of the $\mathrm{CD}^{+} \mathrm{T}$-cell response against a prostate tissue antigen. The effectiveness of activated $\mathrm{T}$ cells in infiltrating and damaging POET prostate was evaluated using adoptive transfer of either $\mathrm{CD}^{+}$or $\mathrm{CD}^{+}{ }^{+} \mathrm{T}$ cells that recognize of $\mathrm{mOVA}$ in prostate tissue. ${ }^{125}$ Additionally, endogenous antigenspecific $\mathrm{CD}^{+} \mathrm{T}$ cells were studied with respect to their ability to recognize and respond to a prostatic selfantigen. Ovalbumin specific cytotoxic CD8 ${ }^{+}$cells were activated by autologous prostate antigen and trafficked to the prostate, but did not induce inflammation unless present in overwhelming numbers $\left(\sim 65 \%\right.$ of $\mathrm{CD}^{+} \mathrm{T}$ cells). Activation of antigen-specific $\mathrm{CD} 8^{+} \mathrm{T}$ cells in vitro (peptide pulsed antigen presenting cells) or in vivo (infection with a replication deficient type 5 adenovirus that encodes mOVA) induced only transitory prostate inflammation, without induction of prostate pathology, regardless of helper-inducer $\mathrm{CD}^{+}{ }^{+} \mathrm{T}$ cell availability. ${ }^{124}$ Cumulatively, these data suggest that the prostate is resistant to $\mathrm{CD}^{+}$immune-mediated epithelial destruction, regardless of the context in which T-cell activation occurs. These observations indicate that immunologically induced prostatitis requires specific antigen(s) presentation and/or manipulation of immune co-stimulatory signaling, specific immunocompetent cell depletion, or specific T-cell activation. These mouse models address the basic principles of cell immune tolerance and self-recognition. Based on current knowledge, these models do not appear promising in furthering our understanding of prostatic inflammation.

\section{Hormone-associated prostatitis models}

\section{Rat models of prostatitis}

The prostate gland is an androgen-dependent organ in males. Therefore, androgens play a key role in the regulation of prostatic growth, function and disease. Supra-physiologic doses of exogenous testosterone do not stimulate additional prostate growth; however, it should be noted that normally occurring neonatal hormone surges may permanently imprint the prostate and determine its future growth in adulthood. ${ }^{126}$ Moreover, severe diffuse prostatitis was induced in $80 \%$ of ventral and $100 \%$ of lateral prostates in young adult (12-week-old) Wistar rats by neonatal treatment with $100 \mu \mathrm{g}$ of $17 \beta$-estradiol (days 2 and 5 of life) followed several months later (weeks 10-12) by testosterone administration ( $2.0 \mathrm{mg} /$ day) for 2 weeks in adulthood. ${ }^{67}$ Grossly both prostates lobes appeared edematous and diffuse sheets of lymphocytes and monocytes, as well as extensive areas of fibrosis, were detected throughout the stroma of the affected lobes. Neither neonatal administration of $17 \beta$-estradiol alone, nor testosterone treatment in adulthood alone was able to initiate prostatitis. ${ }^{67}$ Additionally, more recently it has been shown that perinatal (from dam's gestation day 18 to parturition and then the pups from postnatal day 1-5) exposure to $17 \beta$-estradiol was sufficient to increase the incidence of stromal and lumen inflammation both in the ventral and lateral prostate, as well as hypoplasia and stromal fibrosis. Perinatal tamoxifen (partial estrogen agonist) administration also resulted in similar phenotype responses and prostate inflammation but without fibrosis in the ventral prostate 90 days post-treatment in Wistar rats. ${ }^{127}$ Although, a similar protocol resulted in permanent alteration of the prostate growth with lobespecific changes in androgen receptor expression in the adult prostate, there was no indication of prostate inflammation in neonatal estrogen imprinted SpragueDawley rats. ${ }^{128}$ These data clearly indicate the role of genetic susceptibility to prostatitis observed in different rat strains. Indeed, spontaneous nonbacterial age-related prostatitis is commonly observed in Lewis and Wistar rats, and does not occur in Sprague-Dawley rats. ${ }^{67}$

Treatment of 10- to 13-month-old intact Lewis and Wistar male rats for 30 days with $17 \beta$-estradiol has shown 1.5- to 3-fold increases in the incidence and twoto sixfold in the severity of spontaneously occurring inflammation in the lateral prostate lobes. ${ }^{67}$ Histological sections of these prostates showed severe, multifocal, predominantly chronic inflammation. Sex steroid hormone ablation (castration) had effects comparable to those observed in rats administered estrogen. Concomitant administration of $2.5 \mathrm{mg} / \mathrm{kg} /$ day of testosterone but not the administration of dihydrotestosterone propionate (DHT) reduced the incidence and severity of spontaneous lateral lobe prostatitis induced by $17 \beta$-estradiol. Interestingly, treatment with $17 \beta$-estradiol or castration worsened lateral lobe prostatitis, whereas injections of live cytomegalovirus or heat killed $E$. coli into the ventral prostate did not initiate ventral prostatitis in these animals. ${ }^{67}$ Similar findings were observed in a study of the sub-acute (2-4 weeks) effects of $17 \beta$-estradiol and DHT on the lateral lobe of prostate in 2- to 3-month-old male Wistar rats. ${ }^{129}$ The late effect at 21 weeks of these hormone administrations was intense lateral prostate inflammation; accompanied by a fibromuscular proliferation that consisted with fibroblast, smooth muscle cells and collagen. However, even the administration of the same hormones on a chronic base failed to initiate leukocyte infiltration and/or stromal proliferation in ventral prostate of young adult Wistar rats. ${ }^{129}$

A lateral lobe specific upregulation of proinflammatory genes was observed during estradiol-induced prostate inflammation in young adult Wistar rats. ${ }^{130}$ Based on the pattern of cytokine production of CD4 ${ }^{+} \mathrm{T}-$ helper-inducer cells, responses to infection, allergy and autoimmune conditions have been divided into two classes, designated Th1 and Th2. ${ }^{131}$ The Th1 response has been associated with a variety of chronic inflammatory conditions and autoimmune disorders and the Th1 cytokine pattern is characterized by IFN- $\gamma$ production and macrophage activation. The Th2 response is characterized by production of IL-4, IL-5 and IL-10, which contribute to mast-cell activation, eosinophil influx, and the immediate hypersensitivity response. Although both Th1 and Th2 type immune responses are responsible for proinflammatory cytokine patterns, they tend to downregulate one another. It has been demonstrated that treatment of 8-week-old male non-castrated Wistar rats 
with estrogen resulted in an upregulation of a nonspecific cohort of pro-inflammatory transcripts such as MIP-2, iNOS, IL-6, IL- $1 \beta$ and TNF- $\alpha$ in the lateral prostate after as little as 4 days of treatment, well before any histological evidence of inflammatory cell infiltration was observed. ${ }^{130}$ Further examination of a broader set of cytokines at 4 weeks, exhibited histological signs of inflammation accompanied by upregulation of IL-4, IL-5, IL-10, eotaxin and iNOS transcripts, but with no change in the expression of IL-2, IL-12, COX-2 or IFN- $\gamma$. These expression patterns suggest that the inflammatory process in the lateral prostate lobes of estradiol-exposed rats resembles that of the Th2 helpercell response. ${ }^{130}$

A fundamental aspect of inflammation is infiltration of the interstitial tissue by leukocytes which elaborate matrix metalloproteinases (MMPs) that facilitate clearance of foreign agents and remove damaged cells and extracellular matrix. ${ }^{132}$ To examine the role of MMPs in the pathogenesis of sex hormone induced prostatitis, Wilson et al. ${ }^{129}$ replicated the estrogen-induced lateral lobe-specific prostate inflammation rat model of Robinette et al. They demonstrated matrix metalloproteinases (MMP-2 and MMP-9) activities associated with the chronic prostatitis in the lateral prostate lobe. They noted that these could be significantly reduced by treatment with testosterone, but not DHT. ${ }^{133}$

Currently, there is only one report that supports the autoimmune nature of sex-hormone-induced prostatitis. ${ }^{134}$ Although these investigators used an unusually small number of in vitro activated splenocytes for the adoptive cell transfer, they reported that rat lobe-specific prostatitis can be induced in naive syngeneic recipients by adoptive transfer of spleen $\mathrm{CD}^{+}$T cells from $17 \beta$ estradiol-treated male rat donors. It remains unclear whether this model of prostate inflammation is of autoimmune origin, since there is considerable evidence that $17 \beta$-estradiol is capable of inhibiting physical and histological signs of experimental autoimmune encephalomyelitis (EAE), a mouse model of human multiple sclerosis. ${ }^{135}$ EAE is a classical Th1 type cell-mediated autoimmune disease. ${ }^{136}$ The immunoregulatory effects of $17 \beta$-estradiol in preventing EAE appear to be mediated by direct or indirect inhibition of encephalitogenic Th1 cells, macrophages and dendritic cells. The most dramatic effect of $17 \beta$-estradiol involves strong inhibition of TNF- $\alpha$ by Th1 cells and antigen presenting cells, and it is noteworthy that $17 \beta$-estradiol also enhanced production of TGF- $\beta 3$, which has been shown to have protective effects against EAE when used in combination with other agents. ${ }^{137}$ A novel finding is that $17 \beta$-estradiol upregulates the expression of Foxp3 and CTLA-4, which contribute to the activity of $\mathrm{CD} 4{ }^{+} \mathrm{CD} 25^{+} \mathrm{T}$ regulatory cells. ${ }^{138,139}$

Lateral lobe prostate inflammation in $17 \beta$-estradioltreated male Wistar rat model has been clearly shown to correlate with increased serum prolactin, elevated pituitary weight, and a greater than twofold increase in lateral prostate DNA concentration. ${ }^{140}$ These effects of $17 \beta$-estradiol were blocked by administration of bromocryptine (a dopamine D2 agonist that inhibits pituitary prolactin release). Inflammation was restored in the bromocryptine-treated estradiol-implanted rats by administrating exogenous ovine prolactin. Recently, it has been found that there is a significant association between

spontaneous inflammation in the dorsolateral lobes of prostate and prolactin positive pituitary gland adenomas in Fisher-344 rats; this finding supports the hypothesis that prolactin plays an important role in the pathogenesis of prostatic inflammation. ${ }^{141}$ It has been also shown that prepubertal (postnatal days 22-32) exposure to various compounds that increase prolactin secretion, including pimozide (a dopamine antagonist), bisphenol A (a monomer of polycarbonate plastic reported to have weak estrogenic activity), and $17 \beta$-estradiol, albeit through different mechanisms, can increase the incidence of inflammation in the lateral prostate the Wistar rats. ${ }^{142,143}$

Shyr et al. ${ }^{144}$ used daily injections of bromocryptine to depress maternal plasma and milk PRL levels in lactating rats. Such treatment during only postpartum days 2-5 resulted in a marked suppression of tuberoinfundibular dopamine DA turnover in the median eminence and an elevation of the plasma prolactin concentration in the offspring when measured at $4-5$ weeks of age. ${ }^{144}$ Further, Stoker et al. have shown that suppressed sucklinginduced prolactin release in Wistar dams induced by the herbicide atrazine was associated with lateral prostate inflammation of the adult offspring by about 17 weeks of age. The most critical period for this effect was again postnatal days $1-4 .^{145}$

It is important to note that estrogenization limited to the neonatal period results in both lateral and ventral prostatic inflammation in adulthood, producing a marked prolactin-dependent infiltration of $\mathrm{CD}^{+}$and $\mathrm{CD}^{+}$lymphocytes and a prolactin-independent macrophage accumulation in the adult ventral prostate lobe of Sprague-Dawley rats. ${ }^{146}$ Collectively, these findings suggest that hyperplolactenemia may contribute in the $17 \beta$-estradiol-induced immune response.

Altogether, these studies suggest that the experimental estradiol-induced rat model of prostate inflammation is mediated by hyperprolactinemia. Curiously, although prolactin receptors are more readily detected and quantified in the ventral rat prostate than in the lateral prostate. ${ }^{147}$ The exact mechanism by which hyperprolactinemia induces inflammation in the adult prostate remains to be determined. ${ }^{148}$ It is possible that the inflammatory responses seen in the lateral prostate of adult rats in this model are related to an altered immune function, because studies have shown that hyperprolactinemia or manipulation of prolactin in adults can either enhance or suppress humoral and cellular immune responses. ${ }^{149}$

To investigate the contribution of the immune system in this model of prostate inflammation, Vykhovanets et al. ${ }^{150,151}$ developed a novel protocol to isolate rat intraprostatic lymphocytes. They reported that the lymphocyte populations within whole prostates of healthy Sprague-Dawley rats are unusual in that they contain three subsets of roughly equivalent volume: $\alpha \beta \mathrm{TCR}^{+} \mathrm{T}$ cells, $\mathrm{CD}^{+61 \mathrm{a}^{+}} \alpha \beta \mathrm{TCR}^{-}$natural killer (NK) cells, and $\mathrm{CD}_{161 \mathrm{a}^{+} \alpha \beta \mathrm{TCR}^{+}} \mathrm{NKT}$ cells. ${ }^{150}$ In contrast with spleen, liver, blood, iliac and mesenteric lymph nodes, whole rat prostate contain unexpectedly high numbers of NK cells, T cells bearing NK cell marker (NKT cells) which are predominately CD8 ${ }^{+}$NKT cells, and $\mathrm{CD} 45 \mathrm{RC}^{+} \mathrm{CD} 4^{+} \mathrm{T}$ cells. Subsequent studies replicating the estrogen-induced prostatitis model of Naslund et al. ${ }^{67}$ showed that (i) both rats with spontaneous and 
24 sex-hormone-induced prostatitis show a decreased proportion of intraprostatic NK like cells $\left(\mathrm{CD}_{161 \mathrm{a}^{+}} \alpha \beta \mathrm{TCR}^{-}\right.$ real NK cells and CD161a-bearing (NK-marker) $\alpha \beta \mathrm{TCR}^{+}$ $\mathrm{T}$ cells i.e. NKT cells); (ii) downregulation of the intraprostatic NK-like cells and a low NKT/T cell ratio are reliable markers of sex-hormone-induced lateral prostate inflammation in this model; (iii) decreased proportions of NKT cells in inflamed prostate appear to be due to a decrease in the proportion of CD4 ${ }^{*} \mathrm{NKT}$ cells; (iv) the inflamed lateral prostates show an accumulation of total $\mathrm{CD}^{+} \mathrm{T}$ helper-inducer cells, $\mathrm{CD}_{45 \mathrm{RC}^{+}} \mathrm{CD}^{+} \mathrm{T}$ cell subset and decreased levels of NK cells. $^{151}$ Further analysis of pooled ventral and dorso-lateral lobe intraprostatic lymphocytes revealed that healthy prostates in both Sprague-Dawley and Wistar rats had an unexpectedly low ratio of $\mathrm{CD}^{+} /$ $\mathrm{CD}^{+}$T cells. ${ }^{150,151}$ In contrast, the CD4/CD8 ratio was increased in inflamed prostates. A low CD4/CD8 T cell ratio has also been observed in the normal human prostate. $^{152}$

Altogether these findings may suggest that prostates in rats that are resistant to inflammation show a cellular profile characterized by high levels of cytotoxic CD8 ${ }^{+} \mathrm{T}$ cells, a high NKT/T-cell ratio, and low CD4/CD8T cell ratio. NKT cells are novel T-cell lineage expressing NK cell markers (CD161a/NKR-P1A in rats). ${ }^{153}$ Upon activation, NKT cells produce large amounts of IFN- $\gamma$ and IL-4 ${ }^{154}$ and play an important role in rat autoimmunity ${ }^{155,156}$ NKT cells have been shown to have immunoregulatory functions with a Th2 type immune response deviation in the Wistar-Furth rat whole pancreaticoduodenal transplantation model. ${ }^{157}$ Of note, in young Sprague-Dawley rats which are resistant to spontaneous prostatitis, ${ }^{67}$ the intraprostatic lymphocytes are almost equally divided between NK cells and NKT cells, whereas in similarly aged Wistar rats NK cells predominate. ${ }^{150,151}$

$\mathrm{CD}_{45 \mathrm{RC}^{-} \mathrm{CD}^{+}{ }^{+} \mathrm{T} \text { cells have been termed regulatory } \mathrm{T}}$ cells because of their ability to prevent autoimmune thyroiditis and diabetes in rats. ${ }^{158}$ In contrast, the CD45RC ${ }^{+} \mathrm{CD}^{+} \mathrm{T}$ cell subset may actually promote autoimmune diabetes, wasting and graft-versus-host disease in rats. ${ }^{159,160}$ The balance between these two subsets may be critical for providing adequate cellmediated immunity versus the development of autoimmune disease. In healthy prostates of both Wistar and Sprague-Dawley rats, ${ }^{150,151}$ about $7-8 \%$ of the CD4 ${ }^{+} \mathrm{T}$ cells are $\mathrm{CD} 45 \mathrm{RC}^{+} \mathrm{CD}^{+} \alpha / \beta \mathrm{TCR}^{+} \mathrm{T}$ cells. This value doubles in prostates from old Wistar rats with spontaneous and sex-hormone-induced prostatitis, suggesting an accumulation of autoreactive $\mathrm{CD} 45 \mathrm{RC}^{+} \mathrm{CD} 4{ }^{+}$ $\alpha / \beta \mathrm{TCR}^{+} \mathrm{T}$ cells and the loss of the regulatory $\mathrm{CD}_{45 \mathrm{RC}^{-} \mathrm{CD}^{+} \alpha / \beta \mathrm{TCR}^{+} \mathrm{T} \text { cells. Moreover, the spleens }}$ of young intact Sprague-Dawley rats naturally contain $\sim 5$-fold lower levels of $\mathrm{CD}_{45 \mathrm{RC}^{+} \mathrm{CD} 4{ }^{+} \alpha / \beta \mathrm{TCR}{ }^{+} \mathrm{T}}$ cells than Wistar rats that are susceptible to spontaneous prostatitis. ${ }^{150,151}$ However, it is interesting to note that the proportion of these cells is decreased about twofold in the spleens and lymph nodes of old Wistar rats that have spontaneous and sex-hormone-induced prostatitis. In view of the fact that the ventral prostate is always inflammation free in this model, these data suggest that (i) $\mathrm{CD}_{45 \mathrm{RC}^{+}} \mathrm{CD}^{+} \alpha / \beta \mathrm{TCR}^{+} \mathrm{T}$ cells may migrate from the spleen to the lateral prostate during the development of inflammation; (ii) lower levels of intraprostatic NKT cells and higher levels of $\mathrm{CD}_{45 \mathrm{RC}^{+}} \mathrm{CD}^{+} \alpha / \beta \mathrm{TCR}^{+}$ $\mathrm{T}$ cells in the lymphoid tissue may reflect a genetic susceptibility of Wistar rats to age-related spontaneous prostate inflammation. ${ }^{151}$ More recent studies have shown that although surface prolactin receptor expression on lateral lobe intraprostatic $\mathrm{CD}^{+} \mathrm{T}$ cells was upregulated twofold after castration in 3-month-old Lewis rats after 30 days of daily administration of $17 \beta$ estradiol it was not accompanied by detectable circulating autoantibodies to lateral prostate tissue (Vykhovanets EV et al., unpublished data).

Since the 1980 s the estrogen-induced lateral lobespecific prostate inflammation model has been the most widely studied rodent model of chronic nonbacterial prostatitis and may represent category III prostatitis. It is useful model because the rat strains involved are readily available, and the induction of lobe-specific prostate inflammation in those rats is highly reproducible. It is an inexpensive model and shares some striking similarities to the development and persistence of human chronic nonbacterial prostatitis. Its etiology may be comparable to that in humans, who often develop this condition at a time in life when androgen levels are downregulated. On the other hand, it is still unclear whether this model represents experimentally induced prostatitis, or whether the prostatitis is spontaneous and genetically predetermined, and simply accelerated by androgen deprivation and estrogen treatment. ${ }^{161}$ Another disadvantage of this model is that it is so far restricted to rats, and it is unclear whether mice may be used for this estrogen/androgen derivation model of prostatitis. As most commercially available reagents are developed for use in mice (especially in immunology) studies of this sort in rats are hampered.

\section{Mouse models of prostatitis}

Recently Pakarainen et al. ${ }^{162}$ reported that four of six $(67 \%)$ testosterone-treated $\mathrm{LH}$ receptor knockout (LuR$\mathrm{KO}$ ) mice exhibited marked inflammation in the prostate, characterized by the abundant presence of lymphocytes in stromal tissue and between tissue layers in prostate glands. The 8 week long testosterone replacement regimen started at the prepubertal age of 21 days to restore both anatomical abnormalities and accessory sex organ function in these hypogonadal LuRKO male mice. ${ }^{163-165}$ Additionally, in some LuRKO mice testosterone replacement also induced severe inflammation in the coagulating glands, vasa deferentia, and epididymis. ${ }^{162}$ Long-term administration of testosterone in Lobund-Wistar and Noble rat strains has been shown to induce invasive prostate adenocarcinomas. ${ }^{61,166}$ It has been demonstrated that testosterone alone blocks $17 \beta$-estradiol-induced prostate inflammation, but prostatitis has not been reported to occur in animals treated with testosterone alone. Therefore, the exact mechanisms by which testosterone induces inflammation and/or infection in the urogenital organs of LuRKO mice still remain elusive. It seems likely that this pathology is related to the disturbance of sperm transport to ejaculated semen in the testosterone-treated LuRKO males. ${ }^{162}$ This mouse transgenic model may hold some promise for future studies. Both hormone-induced and immunologically induced prostatitis may potentially be at work in this model. 


\section{Miscellaneous prostatitis models}

Rat models of prostatitis

Gatenbeck et al. ${ }^{167}$ have observed that long-term (10 days) stress stimuli (starvation, low surrounding temperature and small cage) were associated with inflammatory histopathological changes in prostatic tissue in male 9- to 10-week-old Sprague-Dawley rats. These stress stimuli were associated with marked nonbacterial ventral prostatic lobe inflammatory changes that were sparse in the dorso-lateral prostate. ${ }^{168}$ Lang et al. ${ }^{169}$ employed transurethral prostatic instillation of dissolved dinitrobenzenesulfonic (DNBS) acid in 50\% ethanol in phosphate-buffered saline to develop novel model of abacterial prostatitis in 8- to 10-week-old male SpragueDawley rats. They demonstrated that ethanol/DNBSmediated mucosal injury in the ventral prostate resulted in acute inflammation, which peaked between 24 and $48 \mathrm{~h}$. In contrast with tumor necrosis factor- $\alpha$, the interleukin- $1 \beta$ appears to play a role both in the early and late phases of this local inflammation. Sharma et al. ${ }^{64}$ reported that four of five (80\%) of 13- to 14-week-old male Sprague-Dawley rats maintained on soy-free diet for 11 weeks developed severe inflammation only in the lateral prostate, while rats maintained on soy-containing diets or commercial rat chow did not develop any sign of prostatitis. Increased severity and incidence of lateral lobe prostatitis in rats maintained on the soy-free diet coincided with significantly diminished urinary excretion of various phytoestrogens. The authors speculated that dietary soy might play a protective role against the development of prostatitis in rats. Findings contradictory to the above were subsequently reported by Kwon et al., ${ }^{170}$ who studied prostatitis in 8-week-old male Sprague-Dawley rats. In this model, prostatitis was induced by 9 week of oral administration of soy been extract mixture (isoflavone $300 \mathrm{mg} / \mathrm{kg} /$ day: $60 \%$ genistein and $20 \%$ daidzein) and was not accompanied by any changes in serum androgen levels. ${ }^{170}$ Severe prostatic inflammation developed in more than $80 \%(15 / 18)$ of rats, characterized by neutrophil and lymphocyte infiltration in the dorso-lateral but not in the ventral prostatic lobes. The authors speculated that the prostatitis they observed might be attributable to the weak estrogenic effects of isoflavanoids compounds. ${ }^{170}$ The differences in the findings in these two studies may indicate that longterm consumption of different doses of soy derivatives may have different effects on the prostate, related to the estrogenic effects of isoflavone. Thus, although the simplicity of this model is very attractive, the use of soy diet on its derivatives for the production of experimental prostatitis in rats may be problematic.

In another study, Takechi et al. ${ }^{171}$ demonstrated that lymphocytic infiltration and interstitial edema in the ventral prostate could be induced by partial mechanical obstruction of the urethra, being most prominent on day 3 in 12-week-old male Wistar rats. After the release of the nylon ligature from urethra, these prostatic inflammatory changes gradually disappeared. The authors speculated that intraprostatic urinary reflux and penetration of prostatic stromal tissue by low molecular weight substances in the urine may have been responsible for the development of prostatitis in this model.

The above studies attempted to determine which etiologic factors might contribute to the pathogenesis of chronic nonbacterial prostatitis. Estimation of the advantages or limitations of these models is difficult because subsequent studies using these models were not carried out.

\section{Conclusions}

Significant progress in unraveling the underlying mechanisms of prostatitis has been made since the time of Young (1906). ${ }^{172}$ It is sobering to consider, however, that a recent prostate biopsy study demonstrated lack of correlation between prostatitis-like symptoms and identifiable chronic inflammation. ${ }^{173}$ Acknowledging that prostatitis may have a polyetiological nature, several animal models with unique features are available for study. Further study of these models is warranted in view of increasing evidence that chronic prostate inflammation may play a role in the development of human prostate cancer.

\section{Acknowledgements}

Financial Support: Supported by the Sullivan Foundation for the Study of Prostatitis and The James \& Eilleen Dicke Research Endowment funds.

\section{References}

1 Collins MM, Stafford RS, O'Leary MP, Barry MJ. How common is prostatitis? A national survey of physician visits. J Urol 1998; 159: $1224-1228$.

2 Stamey T. Urinary tract infections in males. In: Stamey T (ed). Pathogenesis and Treatment of Urinary Tract Infections. Williams and Wilkins: Baltimore, MD, 1980, pp 342-429.

3 Moon TD, Hagen L, Heisey DM. Urinary symptomatology in younger men. Urology 1997; 50: 700-703.

4 Roberts RO, Lieber MM, Rhodes T, Girman CJ, Bostwick DG, Jacobsen SJ. Prevalence of a physician-assigned diagnosis of prostatitis: the Olmsted County Study of Urinary Symptoms and Health Status Among Men. Urology 1998; 51: 578-584.

5 Nickel JC, Downey J, Hunter D, Clark J. Prevalence of prostatitis-like symptoms in a population based study using the National Institutes of Health Chronic Prostatitis Symptom Index. J Urol 2001; 165: 842-845.

6 Mehik A, Hellstrom P, Lukkarinen O, Sarpola A, Jarvelin M. Epidemiology of prostatitis in Finnish men: a population-based cross-sectional study. BJU Int 2000; 86: 443-448.

7 Tan JK, Png DJ, Liew LC, Li MK, Wong ML. Prevalence of prostatitis-like symptoms in Singapore: a population based study. Singapore Med J 2002; 43: 189-193.

8 Kunishima Y, Matsukawa M, Takahashi S, Itoh N, Hirose T, Furuya $\mathrm{S}$ et al. National institutes of health chronic prostatitis symptom index for Japanese men. Urology 2002; 60: 74-77.

9 Cheah PY, Liong HL, Yuen KH, Teh CL, Khor T, Yang JR et al. Chronic prostatitis: symptom survey with follow-up clinical evaluation. Urology 2003; 61: 60-64.

10 de la Rosette JJ, Hubregtse MR, Meuleman EJ, Stolk-Engelaar MV, Debruyne FM. Diagnosis and treatment of 409 patients with prostatitis syndromes. Urology 1993; 41: 301-307.

11 Krieger JN, Nyberg Jr L, Nickel JC. NIH consensus definition and classification of prostatitis. JAMA 1999; 282: 236-237.

12 Platz EA, De Marzo AM. Epidemiology of inflammation and prostate cancer. J Urol 2004; 171 (2 Part 2): S36-S40.

13 Badalyan RR, Fanarjyan SV, Aghajanyan IG. Chlamydial and ureaplasmal infections in patients with nonbacterial chronic prostatitis. Andrologia 2003; 35: 263-265. 
14 Nickel JC, Downey J, Pontari MA, Shoskes D, Zeitlin SI. A randomized placebo-controlled multicentre study to evaluate the safety and efficacy of finasteride for male chronic pelvic pain syndrome (category IIIA chronic nonbacterial prostatitis). BJU Int 2004; 93: 991-995.

15 Mercader M, Bodner BK, Moser MT, Kwon PS, Park ES, Manecke RG et al. T cell infiltration of the prostate induced by androgen withdrawal in patients with prostate cancer. Proc Natl Acad Sci USA 2001; 98: 14565-14570.

16 Shahed AR, Shoskes DA. Correlation of $\beta$-endorphin and PGE2 levels in prostatic fluid of chronic prostatitis patients with diagnosis and treatment response. J Urol 2001; 166: 1738-1741.

17 Miller LJ, Fischer KA, Goralnick SJ, Litt M, Burleson JA, Albertsen $\mathrm{P}$ et al. Nerve growth factor and chronic prostatitis/ chronic pelvic pain syndrome. Urology 2002; 59: 603-608.

18 Alexander RB, Propert KJ, Schaeffer AJ, Landis JR, Nickel JC, $\mathrm{O}^{\prime}$ Leary MP et al. Ciprofloxacin or tamsulosin in men with chronic prostatitis/chronic pelvic pain syndrome: a randomized, double-blind trial. Ann Int Med 2004; 141: 581-589.

19 Nickel JC, Narayan P, McKay J, Doyle C. Treatment of chronic prostatitis/chronic pelvic pain syndrome with tamsulosin: a randomized double blind trial. J Urol 2004; 171 1594-1597.

20 Nickel JC. The three As of chronic prostatitis therapy: antibiotics, alpha-blockers and anti-inflammatories. What is the evidence? BJU Int 2004; 94: 1230-1233.

21 Kirby RS, Lowe D, Bultitude MI, Shuttleworth KE. Intraprostatic urinary reflux: an aetiological factor in abacterial prostatitis. Br J Urol 1982; 54: 729-731.

22 Persson BE, Ronquist G, Ekblom M. Ameliorative effect of allopurinol on nonbacterial prostatitis: a parallel double-blind controlled study. J Urol 1996; 155: 961-964.

23 McNaughton CO, Wilt T. Allopurinol for chronic prostatitis Cochrane Database Syst Rev 2002; 4: CD001041.

24 Jang TL, Schaeffer AJ. The role of cytokines in prostatitis. World J Urol 2003; 21: 95-99.

25 Alexander RB, Ponniah S, Hasday J, Hebel JR. Elevated levels of proinflammatory cytokines in the semen of patients with chronic prostatitis/chronic pelvic pain syndrome. Urology 1998; 52: 744-749.

26 Orhan I, Onur R, Ilhan N, Ardicoglu A. Seminal plasma cytokine levels in the diagnosis of chronic pelvic pain syndrome. Int J Urol 2001; 8: 495-499.

27 John H, Barghorn A, Funke G, Sulser T, Hailemariam S, Hauri $\mathrm{D}$ et al. Noninflammatory chronic pelvic pain syndrome: immunological study in blood, ejaculate and prostate tissue. Eur Urol 2001; 39: 72-78.

28 Nadler RB, Koch AE, Calhoun EA, Campbell PL, Pruden DL, Bennett CL et al. IL-1 $\beta$ and TNF- $\alpha$ in prostatic secretions are indicators in the evaluation of men with chronic prostatitis I Urol 2000; 164: 214-218.

29 Miller LJ, Fischer KA, Goralnick SJ, Litt M, Burleson JA, Albertsen $\mathrm{P}$ et al. Interleukin-10 levels in seminal plasma: implications for chronic prostatitis-chronic pelvic pain syndrome. I Urol 2002; 167: 753-756.

30 Hochreiter WW, Nadler RB, Koch AE, Campbell PL, Ludwig $\mathrm{M}$, Weidner $\mathrm{W}$ et al. Evaluation of the cytokines interleukin 8 and epithelial neutrophil activating peptide 78 as indicators of inflammation in prostatic secretions. Urology 2000; 56: 1025-1029.

31 Nishimura T, Abe H, Ito H, Ikeda K, Oka F, Yamamoto M. IL1ra versus IL-1 levels in prostatic fluid from prostatitis patients. Urol Int 1998; 60: 92-96.

32 Shoskes DA, Albakri Q, Thomas K, Cook D. Cytokine polymorphisms in men with chronic prostatitis/chronic pelvic pain syndrome: association with diagnosis and treatment response. J Urol 2002; 168: 331-335.

33 Alexander RB, Brady F, Ponniah S. Autoimmune prostatitis: evidence of $\mathrm{T}$ cell reactivity with normal prostatic proteins. Urology 1997; 50: 893-899.
34 Batstone GR, Doble A, Gaston JS. Autoimmune T cell responses to seminal plasma in chronic pelvic pain syndrome (CPPS). Clin Exp Immunol 2002; 128: 302-307.

35 John H, Maake C, Barghorn A, Zbinden R, Hauri D, JollerJemelka HI. Immunological alterations in the ejaculate of chronic prostatitis patients: clues for autoimmunity. Andrologia 2003; 35: 294-299.

36 Klyushnenkova EN, Link J, Oberle WT, Kodak J, Rich C, Vandenbark AA et al. Identification of HLA-DRB1*1501restricted T-cell epitopes from prostate-specific antigen. Clin Cancer Res 2005; 11: 2853-2861.

37 Collins MM, MacDonald R, Wilt TJ. Diagnosis and treatment of chronic abacterial prostatitis: a systematic review. Ann Intern Med 2000; 133: 367-381.

38 Collins MM, Pontari MA, O'Leary MP, Calhoun EA, Santanna J, Landis JR et al. Quality of life is impaired in men with chronic prostatitis: the chronic prostatitis collaborative research network. J Gen Intern Med 2001; 16: 656-662.

39 Coussens LM, Werb Z. Inflammation and cancer. Nature 2002; 420: 860-867.

40 Gerstenbluth RE, Seftel AD, MacLennan GT, Rao RN, Corty $\mathrm{EW}$, Ferguson $\mathrm{K}$ et al. Distribution of chronic prostatitis in radical prostatectomy specimens with up-regulation of bcl-2 in areas of inflammation. J Urol 2002; 167: 2267-2270.

41 Palapattu GS, Sutcliffe S, Bastian PJ, Platz EA, De Marzo AM, Isaacs WB et al. Prostate carcinogenesis and inflammation: emerging insights. Carcinogenesis 2005; 26: 1170-1181.

42 Nelson WG, De Marzo AM, DeWeese TL, Isaacs WB. The role of inflammation in the pathogenesis of prostate cancer. J Urol 2004; 172 (5 Part 2): S6-S11.

43 Sutcliffe S, Zenilman JM, Ghanem KG, Jadack RA, Sokoll LJ, Elliott DJ et al. Sexually transmitted infections and prostatic inflammation/cell damage as measured by serum prostate specific antigen concentration. J Urol 2006; 175: 1937-1942.

44 MacLennan GT, Eisenberg R, Fleshman RL, Taylor JM, Fu P, Resnick MI et al. The influence of chronic inflammation in prostatic carcinogenesis: a 5-year followup study. J Urol 2006; 176: 1012-1016.

45 Lam-Tse WK, Lernmark A, Drexhage HA. Animal models of endocrine/organ-specific autoimmune diseases: do they really help us to understand human autoimmunity? Springer Semin Immunopathol 2002; 24: 297-321.

46 Yang Y, Santamaria P. Lessons on autoimmune diabetes from animal models. Clin Sci (London) 2006; 110: 627-639.

47 Borchers A, Ansari AA, Hsu T, Kono DH, Gershwin ME. The pathogenesis of autoimmunity in New Zealand mice. Semin Arthritis Rheum 2000; 29: 385-399.

48 Grigoriadis N, Tselios T, Deraos S, Orologas A, Deraos G, Matsoukas J et al. Animal models of central nervous system immune-mediated diseases: therapeutic interventions with bioactive peptides and mimetics. Curr Med Chem 2005; 12: 1513-1519.

49 Sauermann U. Making the animal model for AIDS research more precise: the impact of major histocompatibility complex (MHC) genes on pathogenesis and disease progression in SIV-infected monkeys. Curr Mol Med 2001; 1: 515-522.

50 Lubberts E, Koenders MI, van den Berg WB. The role of T-cell interleukin-17 in conducting destructive arthritis: lessons from animal models. Arthr Res Ther 2005; 7: 29-37.

51 Ellinwood NM, Vite $\mathrm{CH}$, Haskins ME. Gene therapy for lysosomal storage diseases: the lessons and promise of animal models. J Gene Med 2004; 6: 481-506.

52 Maragakis NJ, Rothstein JD. Glutamate transporters: animal models to neurologic disease. Neurobiol Dis 2004; 15: 461-473.

53 Grunig G, Kurup VP. Animal models of allergic bronchopulmonary aspergillosis. Front Biosci 2003; 8: e157-e171.

54 Lee A. Animal models of gastroduodenal ulcer disease. Baillieres Best Pract Res Clin Gastroenterol 2000; 14: 75-96.

55 Rubinstein G. Schizophrenia, infection and temperature. An animal model for investigating their interrelationships. Schizophr Res 1993; 10: 95-102. 
56 McMahon AC, Kritharides L, Lowe HC. Animal models of atherosclerosis progression: current concepts. Curr Drug Targets Cardiovasc Haematol Disord 2005; 5: 433-440.

57 Luzzi GA. Chronic prostatitis and chronic pelvic pain in men: aetiology, diagnosis and management. J Eur Acad Dermatol Venereol 2002; 16: 253-256.

58 Sugimura Y, Cunha GR, Donjacour AA. Morphogenesis of ductal networks in the mouse prostate. Biol Reprod 1986; 34: 961-971.

59 Jesik CJ, Holland JM, Lee C. An anatomic and histologic study of the rat prostate. Prostate 1982; 3: 81-97.

60 Greenberg NM, DeMayo F, Finegold MJ, Medina D, Tilley WD, Aspinall JO et al. Prostate cancer in a transgenic mouse. Proc Natl Acad Sci USA 1995; 92: 3439-3443.

61 Pollard M, Luckert PH. Autochthonous prostate adenocarcinomas in Lobund-Wistar rats: a model system. Prostate 1987; 11: 219-227.

62 van Bokhoven A, Varella-Garcia M, Korch C, Johannes WU, Smith EE, Miller HL et al. Molecular characterization of human prostate carcinoma cell lines. Prostate 2003; 57: 205-225.

63 Lundgren R, Holmquist B, Hesselvik M, Muntzing J. Treatment of prostatitis in the rat. Prostate 1984; 5: 277-284.

64 Sharma OP, Adlercreutz H, Strandberg JD, Zirkin BR, Coffey DS, Ewing LL. Soy of dietary source plays a preventive role against the pathogenesis of prostatitis in rats. J Steroid Biochem Mol Biol 1992; 43: 557-564.

65 Keith IM, Jin J, Neal Jr D, Teunissen BD, Moon TD. Cell relationship in a Wistar rat model of spontaneous prostatitis. J Urol 2001; 166: 323-328.

66 Muntzing J, Sufrin G, Murphy GP. Prostatitis in the rat. Scand J Urol Nephrol 1979; 13: 17-22.

67 Naslund MJ, Strandberg JD, Coffey DS. The role of androgens and estrogens in the pathogenesis of experimental nonbacterial prostatitis. J Urol 1988; 140: 1049-1053.

68 Penna G, Amuchastegui S, Cossetti C, Aquilano F, Mariani R, Adorini L. Spontaneous and induced autoimmune prostatitis in the non-obese diabetic mouse. J Urol 2006; 175 (Suppl): 35.

69 Nickel JC. Recommendations for the evaluation of patients with prostatitis. World J Urol 2003; 21: 75-81.

70 Nickel JC. Antibiotics for bacterial prostatitis. J Urol 2000; 163: 1407.

71 Nickel JC, Moon T. Chronic bacterial prostatitis: an evolving clinical enigma. Urology 2005; 66: 2-8.

72 Kaplan L, Lee C, Schaeffer AJ. Effect of castration on experimental bacterial prostatitis in rats. Prostate 1983; 4: 625-630.

73 Nickel JC, Olson ME, Barabas A, Benediktsson H, Dasgupta MK, Costerton JW. Pathogenesis of chronic bacterial prostatitis in an animal model. Br J Urol 1990; 66: 47-54.

74 Rippere-Lampe KE, Lang M, Ceri H, Olson M, Lockman HA, $\mathrm{O}^{\prime}$ Brien AD. Cytotoxic necrotizing factor type 1-positive Escherichia coli causes increased inflammation and tissue damage to the prostate in a rat prostatitis model. Infect Immun 2001; 69: 6515-6519.

75 Rank RG, White HJ, Soloff BL, Barron AL. Cystitis associated with chlamydial infection of the genital tract in male guinea pigs. Sex Transm Dis 1981; 8: 203-210.

76 Jantos CA, Augustin J, Durchfeld-Meyer B, Baumgartner W, Schiefer HG. Experimental genital tract infection with Chlamydia psittaci (GPIC agent) in male rats. Infection 1998; 26: 126-130.

77 Seo SI, Lee SJ, Kim JC, Choi YJ, Kim SW, Hwang TK et al. Effects of androgen deprivation on chronic bacterial prostatitis in a rat model. Int J Urol 2003; 10: 485-491.

78 Cho YH, Lee SJ, Lee JY, Kim SW, Lee CB, Lee WY et al. Antibacterial effect of intraprostatic zinc injection in a rat model of chronic bacterial prostatitis. Int J Antimicrob Agents 2002; 19: 576-582.

79 Lee YS, Han CH, Kang SH, Lee SJ, Kim SW, Shin OR et al. Synergistic effect between catechin and ciprofloxacin on chronic bacterial prostatitis rat model. Int J Urol 2005; 12 383-389.

80 Elkahwaji JE, Ott CJ, Janda LM, Hopkins WJ. Mouse model for acute bacterial prostatitis in genetically distinct inbred strains. Urology 2005; 66: 883-887.

81 Elkahwaji E, Zhong W, Janda LM, Bjorling DE, Bushman W. Chronic prostatic infection and inflammation induce reactive dysplasia and neoplasia in mice. J Urol 2006; 175 (Suppl): 258.

82 Pacheco-Rupil B, Depiante-Depaoli M, Romero RM, Yantorno C. Experimental autoimmune damage to rat male accessory glands (MAG). Am J Reprod Immunol 1981; 1: 255-261.

83 Donadio AC, Depiante-Depaoli M. Inflammatory cells and MHC class II antigens expression in prostate during timecourse experimental autoimmune prostatitis development. Clin Immunol Immunopathol 1997; 85: 158-165.

84 Donadio AC, Gagliano H, Remedi MM, Nowotny E, DepianteDepaoli M. Time-course study of cellular immune response and testosterone metabolism in an autoimmune model for chronic prostatic inflammation. J Urol 1998; 160: 1546-1550.

85 Maccioni M, Rivero V, Riera CM. Autoantibodies against rat prostate antigens. Association of specific IGG2b and IGG2c with the DTH response. J Autoimmun 1996; 9: 485-491.

86 Pacheco-Rupil B, Depiante-Depaoli M, Casadio B. Experimental autoimmune damage to rat male accessory glands. II. T cell requirement in adoptive transfer of specific tissue damage. $\mathrm{Am}$ J Reprod Immunol 1984; 5: 15-19.

87 Galmarini M, Ferro ME, Riera CM. Delayed hypersensitivity and lesions following isoimmunization with modified rat male accessory glands: kinetics of induction. J Reprod Immunol 1988; 13: $147-157$.

88 Moron G, Maletto B, Ropolo A, Pistoresi-Palencia MC. Effect of aging on experimental autoimmune prostatitis: differential kinetics of development. Clin Immunol Immunopathol 1998; 87: 256-265.

89 Casas-Ingaramo A, Depiante-Depaoli M, Pacheco-Rupil B. Activation of cytotoxic cells by syngeneic prostate antigens in experimental autoimmune vesiculo-prostatitis. Autoimmunity 1991; 9: 151-157.

90 Orsilles MA, Depiante-Depaoli M. Oxidative stress-related parameters in prostate of rats with experimental autoimmune prostatitis. Prostate 1998; 34: 270-274.

91 Rivero VE, Iribarren P, Riera CM. Mast cells in accessory glands of experimentally induced prostatitis in male Wistar rats. Clin Immunol Immunopathol 1995; 74: 236-242.

92 Fong L, Ruegg CL, Brockstedt D, Engleman EG, Laus R. Induction of tissue-specific autoimmune prostatitis with prostatic acid phosphatase immunization: implications for immunotherapy of prostate cancer. I Immunol 1997; 159: 3113-3117.

93 Maccioni M, Riera CM, Rivero VE. Identification of rat prostatic steroid binding protein (PSBP) as an immunosuppressive factor. I Reprod Immunol 2001; 50: 133-149.

94 Liu KJ, Chatta GS, Twardzik DR, Vedvick TS, True LD, Spies $\mathrm{AG}$ et al. Identification of rat prostatic steroid-binding protein as a target antigen of experimental autoimmune prostatitis: implications for prostate cancer therapy. J Immunol 1997; 159: $472-480$

95 Maccioni M, Rivero VE, Riera CM. Prostatein (or rat prostatic steroid binding protein) is a major autoantigen in experimental autoimmune prostatitis. Clin Exp Immunol 1998; 112: $159-165$.

96 Gilardoni MB, Rabinovich GA, Oviedo M, Depiante-Depaoli M. Prostate cancer induction in autoimmune rats and modulation of T cell apoptosis. J Exp Clin Cancer Res 1999; 18: 493-504.

97 Keetch DW, Humphrey P, Ratliff TL. Development of a mouse model for nonbacterial prostatitis. J Urol 1994; 152: 247-250.

98 van Blokland SC, Versnel MA. Pathogenesis of Sjogren's syndrome: characteristics of different mouse models for autoimmune exocrinopathy. Clin Immunol 2002; 103: 111-124.

99 Damotte D, Colomb E, Cailleau C, Brousse N, Charreire J, Carnaud C. Analysis of susceptibility of NOD mice to 
spontaneous and experimentally induced thyroiditis. Eur J Immunol 1997; 27: 2854-2862.

100 Rivero VE, Cailleau C, Depiante-Depaoli M, Riera CM, Carnaud C. Non-obese diabetic (NOD) mice are genetically susceptible to experimental autoimmune prostatitis (EAP). J Autoimmun 1998; 11: 603-610.

101 Rivero V, Carnaud C, Riera CM. Prostatein or steroid binding protein (PSBP) induces experimental autoimmune prostatitis (EAP) in NOD mice. Clin Immunol 2002; 105: 176-184.

102 Taguchi O, Kojima A, Nishizuka Y. Experimental autoimmune prostatitis after neonatal thymectomy in the mouse. Clin Exp Immunol 1985; 60: 123-129.

103 Taguchi O, Nishizuka Y. Self tolerance and localized autoimmunity. Mouse models of autoimmune disease that suggest tissue-specific suppressor T cells are involved in self tolerance. J Exp Med 1987; 165: 146-156.

104 Taguchi O, Kontani K, Ikeda H, Kezuka T, Takeuchi M, Takahashi $\mathrm{T}$ et al. Tissue-specific suppressor $\mathrm{T}$ cells involved in self-tolerance are activated extrathymically by self-antigens. Immunology 1994; 82: 365-369.

105 Sakaguchi S, Sakaguchi N, Asano M, Itoh M, Toda M. Immunologic self-tolerance maintained by activated $\mathrm{T}$ cells expressing IL-2 receptor alpha-chains (CD25). Breakdown of a single mechanism of self-tolerance causes various autoimmune diseases. J Immunol 1995; 155: 1151-1164.

106 Sakaguchi S. Naturally arising CD4+ regulatory $t$ cells for immunologic self-tolerance and negative control of immune responses. Annu Rev Immunol 2004; 22: 531-562.

107 Bagavant H, Thompson C, Ohno K, Setiady Y, Tung KS. Differential effect of neonatal thymectomy on systemic and organ-specific autoimmune disease. Int Immunol 2002; 14: 1397-1406.

108 Bagavant H, Tung KS. Failure of CD25+ T cells from lupusprone mice to suppress lupus glomerulonephritis and sialoadenitis. J Immunol 2005; 175: 944-950.

109 Kojima A, Tanaka-Kojima Y, Sakakura T, Nishizuka Y. Spontaneous development of autoimmune thyroiditis in neonatally thymectomized mice. Lab Invest 1976; 34: 550-557.

110 Taguchi O, Nishizuka Y, Sakakura T, Kojima A. Autoimmune oophoritis in thymectomized mice: detection of circulating antibodies against oocytes. Clin Exp Immunol 1980; 40: 540-553.

111 Taguchi O, Nishizuka Y. Autoimmune oophoritis in thymectomized mice: $\mathrm{T}$ cell requirement in adoptive cell transfer. Clin Exp Immunol 1980; 42: 324-331.

112 Taguchi O, Nishizuka Y. Experimental autoimmune orchitis after neonatal thymectomy in the mouse. Clin Exp Immunol 1981; 46: 425-434.

113 Barrett SP, van Driel IR, Tan SS, Alderuccio F, Toh BH, Gleeson PA. Expression of a gastric autoantigen in pancreatic islets results in non-destructive insulitis after neonatal thymectomy. Eur J Immunol 1995; 25: 2686-2694.

114 Linsley PS, Brady W, Urnes M, Grosmaire LS, Damle NK, Ledbetter JA. CTLA-4 is a second receptor for the B cell activation antigen B7. J Exp Med 1991; 174: 561-569.

115 Thompson CB, Allison JP. The emerging role of CTLA-4 as an immune attenuator. Immunity 1997; 7: 445-450.

116 Chambers CA, Allison JP. Costimulatory regulation of T cell function. Curr Opin Cell Biol 1999; 11: 203-210.

117 Leach DR, Krummel MF, Allison JP. Enhancement of antitumor immunity by CTLA-4 blockade. Science 1996; 271: 1734-1736.

118 Kwon ED, Hurwitz AA, Foster BA, Madias C, Feldhaus A, Greenberg NM et al. Manipulation of T cell costimulatory and inhibitory signals for immunotherapy of prostate cancer. Proc Natl Acad Sci USA 1997; 94: 8099-8103.

119 Yang YF, Zou JP, Mu J, Wijesuriya R, Ono S, Walunas T et al. Enhanced induction of antitumor T-cell responses by cytotoxic $\mathrm{T}$ lymphocyte-associated molecule- 4 blockade: the effect is manifested only at the restricted tumor-bearing stages. Cancer Res 1997; 57: 4036-4041.

120 Mokyr MB, Kalinichenko T, Gorelik L, Bluestone JA. Realization of the therapeutic potential of CTLA-4 blockade in low- dose chemotherapy-treated tumorbearing mice. Cancer Res 1998; 58: 5301-5304.

121 Hurwitz AA, Foster BA, Kwon ED, Truong T, Choi EM, Greenberg NM et al. Combination immunotherapy of primary prostate cancer in a transgenic mouse model using CTLA-4 blockade. Cancer Res 2000; 60: 2444-2448.

122 Zhang J, Thomas TZ, Kasper S, Matusik RJ. A small composite probasin promoter confers high levels of prostatespecific gene expression through regulation by androgens and glucocorticoids in vitro and in vivo. Endocrinology 2000; 141: 4698-4710.

123 Andriani F, Nan B, Yu J, Li X, Weigel NL, McPhaul MJ et al. Use of the probasin promoter ARR2PB to express Bax in androgen receptor-positive prostate cancer cells. J Natl Cancer Inst 2001; 93: 1314-1324.

124 Lees JR, Charbonneau B, Hayball JD, Diener K, Brown M, Matusik $\mathrm{R}$ et al. T-cell recognition of a prostate specific antigen is not sufficient to induce prostate tissue destruction. Prostate 2006; 66: 578-590.

125 Kurts C, Carbone FR, Barnden M, Blanas E, Allison J, Heath WR et al. CD4P T-cell help impairs CD8P T-cell deletion induced by cross-presentation of self-antigens and favors autoimmunity. J Exp Med 1997; 186: 2057-2062.

126 Naslund MJ, Coffey DS. The differential effects of neonatal androgen, estrogen and progesterone on adult rat prostate growth. J Urol 1986; 136: 1136-1140.

127 Stoker TE, Robinette CL, Cooper RL. Perinatal exposure to estrogenic compounds and the subsequent effects on the prostate of the adult rat: evaluation of inflammation in the ventral and lateral lobes. Reprod Toxicol 1999; 13: 463-472.

128 Prins GS. Neonatal estrogen exposure induces lobe-specific alterations in adult rat prostate androgen receptor expression. Endocrinology 1992; 130: 3703-3714.

129 Robinette CL. Sex-hormone-induced inflammation and fibromuscular proliferation in the rat lateral prostate. Prostate 1988; 12: 271-286.

130 Harris MT, Feldberg RS, Lau KM, Lazarus NH, Cochrane DE. Expression of proinflammatory genes during estrogen-induced inflammation of the rat prostate. Prostate 2000; 44: 19-25.

131 Abbas AK, Murphy KM, Sher A. Functional diversity of helper T lymphocytes. Nature 1996; 383: 787-793.

132 Quan TE, Cowper SE, Bucala R. The role of circulating fibrocytes in fibrosis. Curr Rheumatol Rep 2006; 8: 145-150.

133 Wilson MJ, Woodson M, Wiehr C, Reddy A, Sinha AA. Matrix metalloproteinases in the pathogenesis of estradiol-induced nonbacterial prostatitis in the lateral prostate lobe of the Wistar rat. Exp Mol Pathol 2004; 77: 7-17.

134 Seethalakshmi L, Bala RS, Malhotra RK, Austin-Ritchie T, Miller-Graziano C, Menon M et al. 17 beta-estradiol induced prostatitis in the rat is an autoimmune disease. J Urol 1996; 156: 1838-1842.

135 Offner H. Neuroimmunoprotective effects of estrogen and derivatives in experimental autoimmune encephalomyelitis: therapeutic implications for multiple sclerosis. I Neurosci Res 2004; 78: 603-624.

136 Paterson PY. Demyelinating diseases of the central peripheral nervous systems. In: Swanborg RH, Sampter M, Talmage DW, Frank MM, Austen KF, Claman HN (eds). Immunological Diseases. Little, Brown and Co: Boston, 1988, pp 1877-1916.

137 Matejuk A, Dwyer J, Hopke C, Vandenbark AA, Offner H. Opposing roles for TGF-beta1 and TGF-beta3 isoforms in experimental autoimmune encephalomyelitis. Cytokine 2003; 25: $45-51$

138 Polanczyk MJ, Carson BD, Subramanian S, Afentoulis M, Vandenbark AA, Ziegler SF et al. Cutting edge: estrogen drives expansion of the CD4+CD25+ regulatory T cell compartment. J Immunol 2004; 173: 2227-2230.

139 Polanczyk MJ, Hopke C, Huan J, Vandenbark AA, Offner H. Enhanced FoxP3 expression and Treg cell function in pregnant and estrogen-treated mice. J Neuroimmunol 2005; 170: 85-92. 
140 Tangbanluekal L, Robinette CL. Prolactin mediates estradiolinduced inflammation in the lateral prostate of Wistar rats. Endocrinology 1993; 132: 2407-2416.

141 Suwa T, Nyska A, Peckham JC, Hailey JR, Mahler JF, Haseman $\mathrm{JK}$ et al. A retrospective analysis of background lesions and tissue accountability for male accessory sex organs in Fischer344 rats. Toxicol Pathol 2001; 29: 467-478.

142 Stoker TE, Cooper RL, Laws SC, Robinette CL. Elevated prolactin (PRL) prior to puberty and the development of prostatitis in adult Wistar rats. Toxicologist 1999; 43: 145.

143 Stoker TE, Robinette CL, Britt BH, Laws SC, Cooper RL. Prepubertal exposure to compounds that increase prolactin secretion in the male rat: effects on the adult prostate. Biol Reprod 1999; 61: 1636-1643.

144 Shyr SW, Crowley WR, Grovenor CE. Effect of neonatal prolactin deficiency on prepubertal tuberoinfundibular and tuberohypophyseal dopaminergic neuronal activity. Endocrinology 1986; 119: 1217-1221.

145 Stoker TE, Robinette CL, Cooper RL. Maternal exposure to atrazine during lactation suppresses suckling-induced prolactin release and results in prostatitis in the adult offspring. Toxicol Sci 1999; 52: 68-79.

146 Gilleran JP, Putz O, DeJong M, DeJong S, Birch L, Pu Y et al. The role of prolactin in the prostatic inflammatory response to neonatal estrogen. Endocrinology 2003; 144: 2046-2054.

147 Thompson SA, Johnson MP, Brooks CL. Biochemical and immunohistochemical characterization of prolactin binding in rat ventral, lateral, and dorsal prostate lobes. Prostate 1982; 3: $45-58$.

148 Reiter E, Hennuy B, Bruyninx M, Cornet A, Klug M, McNamara $\mathrm{M}$ et al. Effects of pituitary hormones on the prostate. Prostate 1999; 38: 159-165.

149 Berczi I. Pituitary hormones and immune function. Acta Paediatr 1997; 423 (Suppl): 70-75.

150 Vykhovanets EV, Resnick MI, Marengo SR. The healthy rat prostate contains high levels of natural killer-like cells and unique subsets of CD4+ helper-inducer T cells: implications for prostatitis. J Urol 2005; 173: 1004-1010.

151 Vykhovanets EV, Resnick MI, Marengo SR. Intraprostatic lymphocyte profiles in aged Wistar rats with estradiol induced prostate inflammation. J Urol 2006; 175: 1534-1540.

152 Bostwick DG, de la Roza G, Dundore P, Corica FA, Iczkowski KA. Intraepithelial and stromal lymphocytes in the normal human prostate. Prostate 2003; 55: 187-193.

153 Godfrey DI, MacDonald HR, Kronenberg M, Smyth MJ, Van Kaer L. NKT cells: what's in a name? Nat Rev Immunol 2004; 4: 231-237.

154 Yoshimoto T, Paul WE. CD4pos, NK1.1pos T cells promptly produce interleukin-4 in response to in vivo challenge with antiCD3. J Exp Med 1994; 179: 1285-1295.

155 Iwakoshi NN, Greiner DL, Rossini AA, Mordes JP. Diabetes prone $\mathrm{BB}$ rats are severely deficient in natural killer $\mathrm{T}$ cells. Autoimmunity 1999; 31: 1-14.

156 Shao H, Van Kaer L, Sun SL, Kaplan HJ, Sun D. Infiltration of the inflamed eye by NKT cells in a rat model of experimental autoimmune uveitis. J Autoimmun 2003; 21: 37-45.

157 Tori M, Ito T, Yumiba T, Maeda A, Sawai T, Miyasaka M et al. Significant role of intragraft lymphoid tissues in preventing insulin-dependent diabetes mellitus recurrence in whole pancreaticoduodenal transplantation. Microsurgery 1999; 19: 338-343.

158 Seddon B, Mason D. Peripheral autoantigen induces regulatory T cells that prevent autoimmunity. J Exp Med 1999; 189: 877-882.

159 Saoudi A, Seddon B, Fowell D, Mason D. The thymus contains a high frequency of cells that prevent autoimmune diabetes on transfer into prediabetic recipients. J Exp Med 1996; 184: 2393-2398.

160 Xystrakis E, Bernard I, Dejean AS, Alsaati T, Druet P, Saoudi A. Alloreactive CD4T lymphocytes responsible for acute and chronic graft-versus-host disease are contained within the CD45RChigh but not the CD45RClow subset. Eur J Immunol 2004; 34: 408-417.

161 Montironi R, Pomante R, Diamanti L, Magi-Galluzzi C. Apoptosis in prostatic adenocarcinoma following complete androgen ablation. Urol Int 1998; 60 (Suppl 1): 25-29.

162 Pakarainen T, Zhang FP, Makela S, Poutanen M, Huhtaniemi I. Testosterone replacement therapy induces spermatogenesis and partially restores fertility in luteinizing hormone receptor knockout mice. Endocrinology 2005; 146: 596-606.

163 Zhang FP, Poutanen M, Wilbertz J, Huhtaniemi I. Normal prenatal but arrested postnatal sexual development of luteinizing hormone receptor knockout (LuRKO) mice. Mol Endocrinol 2001; 15: 172-183.

164 Zhang FP, Pakarainen T, Zhu F, Poutanen M, Huhtaniemi I. Molecular characterization of postnatal development of testicular steroidogenesis in luteinizing hormone receptor knockout mice. Endocrinology 2004; 145: 1453-1463.

165 Lei ZM, Mishra S, Zou W, Xu B, Foltz M, Li X et al. Targeted disruption of luteinizing hormone/human chorionic gonadotropin receptor gene. Mol Endocrinol 2001; 15: 184-200.

166 Drago JR. The induction of NB rat prostatic carcinomas. Anticancer Res 1984; 4: 255-256.

167 Gatenbeck L, Aronsson A, Dahlgren S, Johansson B, Stromberg L. Stress stimuli-induced histopathological changes in the prostate: an experimental study in the rat. Prostate 1987; 11: 69-76.

168 Aronsson A, Dahlgren S, Gatenbeck L, Stromberg L. Predictive sites of inflammatory manifestation in the prostatic gland: an experimental study on nonbacterial prostatitis in the rat. Prostate 1988; 13: 17-24.

169 Lang MD, Nickel JC, Olson ME, Howard SR, Ceri H. Rat model of experimentally induced abacterial prostatitis. Prostate 2000; 45: 201-206.

170 Kwon SM, Kim SI, Chun DC, Cho NH, Chung BC, Park BW et al. Development of rat prostatitis model by oral administration of isoflavone and its characteristics. Yonsei Med J 2001; 42: 395-404.

171 Takechi S, Yokoyama M, Tanji N, Nishio S, Araki N. Nonbacterial prostatitis caused by partial urethral obstruction in the rat. Urol Res 1999; 27: 346-350.

172 Young HH, Geraghty JT, Stevens AR. Chronic prostatitis. An experimental and clinical study with an analysis of 358 cases. Johns Hopkins Hospital Rep 1906; 13: 271-384.

173 Nickel JC, Bostwick DG, Somerville MC. Lack of relationship between clinical prostatitis and prostate inflammation: baseline data from the reduce trail. J Urol 2006; 175 (Suppl): 31. 